\title{
PMP22 Is Critical for Actin-Mediated Cellular Functions and for Establishing Lipid Rafts
}

\author{
Sooyeon Lee, ${ }^{1}$ Stephanie Amici, ${ }^{1}$ Hagai Tavori, ${ }^{2}$ Waylon M. Zeng, ${ }^{1}$ Steven Freeland, ${ }^{1}$ Sergio Fazio, ${ }^{2}$ \\ and Lucia Notterpek ${ }^{1}$ \\ ${ }^{1}$ Departments of Neuroscience and Neurology, McKnight Brain Institute, College of Medicine, University of Florida, Gainesville, Florida 32611, and 2Knight \\ Cardiovascular Institute, Center of Preventive Cardiology, Oregon Health and Science University, Portland, Oregon 97239
}

\begin{abstract}
Haploinsufficiency of peripheral myelin protein 22 (PMP22) causes hereditary neuropathy with liability to pressure palsies, a peripheral nerve lesion induced by minimal trauma or compression. As PMP22 is localized to cholesterol-enriched membrane domains that are closely linked with the underlying actin network, we asked whether the myelin instability associated with PMP22 deficiency could be mediated by involvement of the protein in actin-dependent cellular functions and/or lipid raft integrity. In peripheral nerves and cells from mice with PMP22 deletion, we assessed the organization of filamentous actin (F-actin), and actin-dependent cellular functions. Using in vitro models, we discovered that, in the absence of PMP22, the migration and adhesion capacity of Schwann cells and fibroblasts are similarly impaired. Furthermore, PMP22-deficient Schwann cells produce shortened myelin internodes, and display compressed axial cell length and collapsed lamellipodia. During early postnatal development, F-actin-enriched Schmidt-Lanterman incisures do not form properly in nerves from PMP $22^{-I-}$ mice, and the expression and localization of molecules associated with uncompacted myelin domains and lipid rafts, including flotillin-1, cholesterol, and GM1 ganglioside, are altered. In addition, we identified changes in the levels and distribution of cholesterol and ApoE when PMP22 is absent. Significantly, cholesterol supplementation of the culture medium corrects the elongation and migration deficits of PMP22 ${ }^{-I-}$ Schwann cells, suggesting that the observed functional impairments are directly linked with cholesterol deficiency of the plasma membrane. Our findings support a novel role for PMP22 in the linkage of the actin cytoskeleton with the plasma membrane, likely through regulating the cholesterol content of lipid rafts.
\end{abstract}

Key words: actin cytoskeleton; cholesterol; lipid rafts; myelin; neuropathy; Schwann cell

\section{Introduction}

Peripheral myelin protein 22 (PMP22) is a neuropathy-linked glycoprotein whose role in peripheral nerve myelination is unclear (Li et al., 2013). Hereditary neuropathy with liability to pressure palsies, a condition that in rare cases is associated with the PMP22-null genotype (Saporta et al., 2011; Li et al., 2013), is diagnosed in individuals with heterozygous deletion of the PMP22 gene. In transgenic mice, the absence of PMP22 causes delayed myelination, dysmyelination, and tomacula formation (Adlkofer et al., 1995; Amici et al., 2006, 2007). How reduced dosage of, or the absence of, PMP22 leads to myelination defects is not fully understood, but compromised signaling via the $\alpha 6 \beta 4$

Received April 18, 2014; revised 0ct. 5, 2014; accepted 0ct. 23, 2014.

Author contributions: S.L., S.A., H.T., S. Fazio, and L.N. designed research;S.L., S.A., H.T., W.M.Z., S. Freeland, and L.N. performed research;S.L., H.T., S. Fazio, and L.N. analyzed data; S.L., S.A., H.T., S. Fazio, and L.N. wrote the paper.

These studies were supported in part by grants from the National Institutes of Health, the Facial Pain Research Foundation, and Tom and Susie Wasdin (L.N.); and the University of Florida University Scholars Program (S.Freeland., W.M.Z.). We thank Dr. Klaus Nave for insightful comments concerning this project, and Dr. Kassidy Chauncey for technical assistance. We also acknowledge past and current Notterpek laboratory members for help with tissue collection and genotyping.

The authors declare no competing financial interests.

Correspondence should be addressed to Dr. Lucia Notterpek, 1149 South Newell Drive, P.0. Box 100244, Gainesville, FL 32611. E-mail: Notterpek@ufl.edu.

DOI:10.1523/JNEUROSCI.1908-14.2014

Copyright $\odot 2014$ the authors $\quad 0270-6474 / 14 / 3416140-13 \$ 15.00 / 0$ integrin complex (Amici et al., 2006) and altered junctional permeability (Guo et al., 2014) are likely to contribute.

Peripheral nerve myelination involves a series of functionally distinctive phases, including longitudinal Schwann cell migration, association with specific axon segments, membrane wrapping, and compaction (Jessen and Mirsky, 2005). These dynamic alterations in cell shape and motility require constant rearrangement of the actin cytoskeleton. A role for filamentous actin (Factin) in the linkage of glial membrane proteins has been long recognized (Trapp et al., 1989), and a number of actin regulatory proteins are now known to be critical for myelination. In oligodendrocytes, calcium/calmodulin-dependent kinase type II regulates myelination by stabilizing the actin cytoskeleton (Waggener et al., 2013), while in the PNS, profilin 1, an actinbinding protein, is essential for myelination through mediating cytoskeletal remodeling (Montani et al., 2014).

Independent studies in multiple cell types indicate that underexpression and overexpression of PMP22 have profound effects on cell membrane dynamics and motility (Brancolini et al., 1999, 2000; Roux et al., 2005; Zoltewicz et al., 2012), functions requiring alterations in the actin cytoskeleton. A potential link between PMP22 and actin is supported by the irregular distribution of F-actin in PMP22 mutant Trembler J mice (Kun et al., 2012). In normal nerves, PMP22 is localized to detergent-insoluble lipid rafts (Erne et al., 2002; Hasse et al., 2002), which are known to 
interact with F-actin in oligodendrocytes (Taguchi et al., 2005). Lipid rafts are enriched in cholesterol, which is essential for myelin expansion (Saher et al., 2009). Recently, we identified palmitoylated PMP22 (Zoltewicz et al., 2012), a finding that further supports the association of this hydrophobic tetraspan protein with lipid rafts (Linder and Deschenes, 2007).

Based on the cited discoveries concerning the role of F-actin in membrane dynamics, the linkage of F-actin to lipid rafts, and the localization of PMP22 in cholesterol-enriched microdomains, we tested the hypothesis that PMP22 is critical for actin-mediated cellular functions and for the integrity of cholesterol-enriched lipid rafts. Using cells and nerves from a PMP22-deficient mouse model (Amici et al., 2006, 2007), we identified impairments in cell adhesion, migration, and membrane expansion, activities that require actin remodeling. In the absence of PMP22, the distribution and levels of key lipid raft constituents, including cholesterol, is altered, while PMP22-linked cellular defects can be rescued by cholesterol supplementation.

\section{Materials and Methods}

Mouse colony. The PMP22-deficient mice used in these studies are missing the first two coding exons of PMP22 (exons 2 and 3), which were replaced with lacZ (Amici et al., 2006). Mice were maintained under specific pathogen-free housing at the animal facility of the University of Florida. PMP22 heterozygote males and females were bred to generate WT $\left(\mathrm{PMP}_{2} 2^{+/+}\right), \mathrm{PMP}^{+/-}$, and PMP-deficient $\left(\mathrm{PMP}^{-1-}\right)$ littermates. Genotypes were determined by Southern blotting (Amici et al., 2006). All experiments in this study used cells and tissues from male and female PMP $22^{+/+}$and PMP22 ${ }^{-/-}$littermates.

Serum cholesterol and apolipoprotein E measurements. Fasting serum cholesterol and triglyceride concentrations were measured in 6-week-old mice ( $n=3-4$ mice per genotype) using a colorimetric method. The serum lipoprotein distribution was determined by size exclusion chromatography [fast protein liquid chromatography (FPLC)], as previously described (Tavori et al., 2013). Apolipoprotein E (ApoE) detection and quantification was performed using $2 \mu \mathrm{l}$ of serum loaded onto NuPage $4-12 \%$ Bis-Tris precast gels for electrophoresis. Goat anti-ApoE (R\&D Systems) and rabbit anti-goat horseradish peroxidase (HRP; Sigma) antibodies were used for murine ApoE detection. Intensity quantification of the bands was obtained using ImageJ software (Abramoff et al., 2004).

Cell culture studies. Dorsal root ganglia (DRGs) explants were isolated from embryonic day 14 (E14) to E16 mouse pups and plated on collagencoated coverslips (Rangaraju et al., 2008, 2010). After 6 d in vitro, cultures were induced to myelinate by the addition of $50 \mu \mathrm{g} / \mathrm{ml}$ ascorbic acid (Sigma) to the media, for up to 2 weeks. Primary mouse Schwann cells were cultured from postnatal day 5 (P5) to P18 sciatic nerves. Nerves from killed mice were dissected into DMEM supplemented with Ham's F12 (DMEM-F12; Invitrogen), 10\% fetal bovine serum (FBS; Hyclone), and gentamicin $\left(20 \mu \mathrm{g} / \mathrm{ml}\right.$; Invitrogen), and were kept at $37^{\circ} \mathrm{C}$ for up to $7 \mathrm{~d}$. Nerves were dissociated by digestion with collagenase and dispase, followed by mechanical trituration and plating (Fortun et al., 2007). Fibroblasts were eliminated with $5 \mu \mathrm{M}$ cytosine arabinoside (Sigma) supplementation for $4 \mathrm{~d}$. Schwann cells were expanded in DMEM-F12 with $10 \%$ FBS and $10 \mu \mathrm{g} / \mathrm{ml}$ bovine pituitary extract (Biomedical Technologies Inc), and $2 \mu \mathrm{M}$ forskolin (Calbiochem). For cholesterol depletion, Schwann cells were plated on poly-L-lysine (PL)-coated coverslips for 24-48 h using DMEM-F12 media supplemented with 10\% lipoproteindeficient FBS (Sigma), bovine pituitary extract $(10 \mu \mathrm{g} / \mathrm{ml}$; Biomedical Technologies Inc), and forskolin (2 $\mu \mathrm{M}$; Calbiochem). Free cholesterol (Sigma) was dissolved at $10 \mathrm{mg} / \mathrm{ml}$ into $100 \%$ ethanol and added to the cells at a final concentration of $20 \mu \mathrm{g} / \mathrm{ml}$. Cholesterol was added for $24 \mathrm{~h}$, and control cultures were treated with equal volumes of ethanol without cholesterol. Mouse embryonic fibroblasts (MEFs) were harvested from E13 to E16 embryos (Takahashi and Yamanaka, 2006). All experiments were performed with Schwann cells passaged less than three times and up to six times for fibroblasts.
Peripheral nerve staining. Sciatic nerves were either teased into individual fibers or frozen in liquid nitrogen cooled $N$-methyl butane and sectioned before staining. For F-actin alone, or for F-actin and flotillin-1 staining, freshly isolated nerves were immersed in $4 \%$ paraformaldehyde in $0.1 \mathrm{M}$ PBS for $30 \mathrm{~min}$ at room temperature (RT), after which individual fibers were teased onto Superfrost slides, dried for $1 \mathrm{~h}$, permeabilized with $0.2 \%$ Triton X-100 in $0.1 \mathrm{M}$ PBS for $30 \mathrm{~min}$, and blocked with $5 \%$ normal goat serum (NGS) for $30 \mathrm{~min}$. Alexa Fluor 488-conjugated phalloidin (1:500; Invitrogen) and rabbit anti-flotillin 1 antibody (1:200; Abcam) were diluted in blocking buffer, and applied for $24 \mathrm{~h}$ at $4^{\circ} \mathrm{C}$. For immunodetection of ApoE (Abcam) and S-100 $\beta$-subunit (Sigma), nerve sections were incubated with the primary antibodies overnight at $4^{\circ} \mathrm{C}$. Secondary antibodies (Alexa Fluor 594 goat anti-rabbit IgG and Alexa Fluor 488 goat anti-mouse IgG; Invitrogen) were added for $1 \mathrm{~h}$. The number of Schmidt-Lanterman incisures (SLIs) per unit length of nerve $(100 \mu \mathrm{m})$, and SLI length/width measurements were obtained using established methodologies (Yin et al., 2008; Jung et al., 2011). For filipin labeling, longitudinal nerve cryosections ( $5 \mu \mathrm{m}$ thickness) were fixed with 4\% paraformaldehyde (Electron Microscopy Sciences) in PBS for 10 min, dried for $1 \mathrm{~h}$, and rinsed twice in PBS. Next, tissues were incubated with $0.2 \mathrm{mg} / \mathrm{ml}$ filipin (Sigma) diluted in PBS (Strauss et al., 2010; Saher et al., 2012). Quantification of filipin-cholesterol fluorescence was performed using ImageJ software. For cholera toxin subunit $\beta(\mathrm{Ctx}-\beta)$ labeling, cryosections were fixed with $4 \%$ paraformaldehyde in PBS for 10 min and incubated in cold acetone for $10 \mathrm{~min}$ (Petr et al., 2010). Samples were rinsed, blocked with 5\% BSA in PBS, and incubated with $20 \mu \mathrm{g} / \mathrm{ml}$ Alexa Fluor 594 Ctx- $\beta$ (Invitrogen). Nuclei were stained with Hoechst dye (Invitrogen), and tissues were mounted using Prolong Antifade media (Invitrogen).

Cholesterol measurements in nerve extracts. Between 5 and $9 \mathrm{mg}$ of sciatic nerve tissue were extracted with $200 \mu$ l of chloroform/ isopropanol/NP-40 (7:11:0.1) in a microhomogenizer. Organic phase was dried under nitrogen stream, and the dried lipid extraction was dissolved in $150 \mu \mathrm{l}$ of cholesterol assay buffer (Abcam) and analyzed using the colorimetric method.

Biochemical studies. Sciatic nerves from WT and PMP22 $2^{-1-}$ mice $(n=$ 3-6 animals per group, per experiment) were processed for Western blotting (Amici et al., 2006). Cultured cells were lysed in SDS gel sample buffer (62.5 mm Tris, pH 6.8, 10\% glycerol, and 3\% SDS), supplemented with complete protease (Roche) and phosphatase (Sigma) inhibitors. Samples were separated on $7.5 \%$ or $10 \%$ acrylamide gels under reducing conditions and transferred to nitrocellulose membranes (Bio-Rad). Blots were probed with the following antibodies: rabbit anti-PMP22 (Pareek et al., 1997; Amici et al., 2006); rabbit anti- $\beta$-galactosidase ( $\beta$-gal; Abcam); rat anti-E-cadherin (Sigma); goat anti-ApoE (Millipore); mouse antimyelin associated glycoprotein (MAG, Millipore); anti- $\alpha$-tubulin and anti-actin (Sigma); anti-glyceraldehyde-3-phosphate dehydrogenase (GAPDH; EnCor Biotechnology); vinculin (Sigma); and flotillin-1 (Abcam). For analyses of the carbohydrate modification of PMP22, total cell lysates $(30 \mu \mathrm{g})$ were treated with $\mathrm{N}$-glycosidase $\mathrm{F}$ or endoglycosidase $\mathrm{H}$ (endoH; New England Biolabs), according to the manufacturer's instructions. Proteins were separated on $12.5 \%$ acrylamide gels, then transferred to PVDF membranes and probed with a polyclonal anti-PMP22 antibody (Pareek et al., 1997; Amici et al., 2006). Appropriate horseradish peroxidase-conjugated secondary antibodies (Cell Signaling Technology) were applied for $1 \mathrm{~h}$, and bound antibodies were visualized with ECL (PerkinElmer). Films were digitally imaged using a GS-710 densitometer (Bio-Rad) and formatted for printing by using Adobe Photoshop CS2.

Immunocytochemistry. Schwann cells or MEFs were fixed in 4\% paraformaldehyde and permeabilized in $0.2 \%$ Triton X-100 for $15 \mathrm{~min}$ at RT, or in $100 \%$ methanol (for DRG explants), and were then blocked in 5\% NGS in PBS for $1 \mathrm{~h}$ at RT. Following incubation with rat anti-myelin basic protein (MBP; Millipore), rabbit anti-p75NTR (Millipore Bioscience Research Reagents), rabbit anti-ApoE (Abcam), and mouse anti-S$100 \beta$-subunit (Sigma) or mouse anti-vinculin (Sigma) antibodies overnight at $4^{\circ} \mathrm{C}$, the appropriate Alexa Fluor-conjugated secondary antibodies were applied for $2 \mathrm{~h}$. Nuclei were stained with Hoechst dye. For surface Ctx- $\beta$ binding, cells were rinsed twice in cold $0.1 \mathrm{M}$ PBS and incubated with $20 \mu \mathrm{g} / \mathrm{ml} \mathrm{Ctx}-\beta$ (Invitrogen) diluted in $0.1 \mathrm{M}$ PBS with 0.1 
$\mathrm{M} \mathrm{Mg}_{2} \mathrm{SO}_{4}$ for 30 min on ice (Lee et al., 2013). Samples were rinsed three times in PBS, fixed in $4 \%$ paraformaldehyde for $10 \mathrm{~min}$ at RT, and were then counterstained for $24 \mathrm{~h}$ at $4^{\circ} \mathrm{C}$ with Alexa Fluor 488-conjugated phalloidin (10 $\mu \mathrm{g} / \mathrm{ml}$; Invitrogen) diluted in PBS. For filipin staining, cells were fixed with $4 \%$ paraformaldehyde in PBS for $10 \mathrm{~min}$ at RT, and incubated with $2 \mathrm{mg} / \mathrm{ml}$ filipin (Sigma) diluted in PBS. For cell surface labeling, cultures were incubated with $1 \mu \mathrm{M}$ FM143-X (Invitrogen) for 30 min in normal media, then rinsed twice in PBS and fixed with $4 \%$ paraformaldehyde for $5 \mathrm{~min}$. Coverslips were mounted using the ProLong Antifade media (Invitrogen). Samples were imaged within $24 \mathrm{~h}$ using a Spot camera attached to a Nikon Eclipse E800 or Leica spinning disk confocal microscope. All images were acquired with identical settings, and postacquisition formatting was performed using Adobe Photoshop CS5.

Morphometrics. Schwann cells immunostained with anti-P75NTR antibodies or labeled with FM143 were used to analyze cell length, and anti-MBP antibody reactive myelin segments were measured for evaluating internode lengths in the myelination assays. The axial length was defined as the longest axis of the cell and was measured using ImageJ (http://rsbweb.nih.gov/ij/index.html). Values were exported to Microsoft Excel to calculate means and SEMs. Measurements were performed blindly on three independent samples for each genotype and treatment, and were repeated two to three times.

Cell adhesion assays. Ninety-six-well microtiter plates were coated for $2 \mathrm{~h}$ at $37^{\circ} \mathrm{C}$ with $10 \mu \mathrm{g} / \mathrm{ml}$ laminin (Promega), $3 \%(\mathrm{w} / \mathrm{v}$ ) bovine serum albumin (BSA), or $5 \mu \mathrm{g} / \mathrm{ml}$ fibronectin (Sigma) in DMEM. Plates were then blocked with $1 \%$ BSA in DMEM for $1 \mathrm{~h}$ at $37^{\circ} \mathrm{C}$. Freshly dissociated cells $(10,000$ cells/well) in normal culture media were allowed to adhere at $37^{\circ} \mathrm{C}$ for $30 \mathrm{~min}$ for Schwann cells or $10 \mathrm{~min}$ for fibroblasts, and then fixed in $1 \%$ glutaraldehyde for $15 \mathrm{~min}$ at RT. Wells were stained with $0.1 \%$ crystal violet (Sigma) in water for $30 \mathrm{~min}$ at RT, dried, and permeabilized in $0.3 \%$ Triton X-100 in PBS. Absorbance at $550 \mathrm{~nm}$ was measured in a microplate reader (Bio-Rad), and data were graphed and analyzed using Microsoft Excel. A positive correlation between the number of adhered cells and the absorbance value obtained has been established (Aumailley et al., 1989). Assays were repeated at least three times to verify results, with each assay containing four wells per condition. Statistical significance was determined using an unpaired, two-tailed Student's $t$ test (Excel, Microsoft).

Cell migration assays. Cell migration was measured using modifications from Meintanis et al. (2001). Cells $\left(5 \times 10^{4}\right)$ were plated in $40 \mu \mathrm{l}$ drops on PL or laminin-coated glass coverslips in normal growth medium. Twenty-four hours later, the medium was changed to $2 \%$ FCS/ DMEM, and cells were incubated for $12 \mathrm{~h}$. For testing cholesteroldepleted conditions, cells were plated in media with $10 \%$ lipoproteindeficient serum and kept for 24-48 h. The cell monolayer was gently scratched with a sterile micropipette tip to generate a $\sim 1$-mm-wide gap. Immediately after scratching $(t=0 \mathrm{~h}), 10 \%$ FCS/DMEM was added, and migration of the cells within the gap was monitored microscopically at $t=0 \mathrm{~h}$ and $t=8 \mathrm{~h}$ using a Nikon T1-SM inverted microscope equipped with a Nikon DS-L1 camera. The gaps were asymmetrically marked with a needle along the scratches, and images at $t=0 \mathrm{~h}$ and $t=8 \mathrm{~h}$ were overlapped and aligned in Photoshop CS2. Over a period of $8 \mathrm{~h}$, the area migrated by the cells was measured using ImageJ software (National Institutes of Health). The difference between the areas [(initial area at $t=$ $0 \mathrm{~h})-($ area at $t=8 \mathrm{~h})]$ was then calculated. Assays were repeated at least three times to verify the results. Statistical significance was determined using an unpaired, two-tailed Student's $t$ test (Excel, Microsoft). Migration was observed for only $8 \mathrm{~h}$ to ensure that the presence of cells within the gap was due to movement and not proliferation. Parallel cultures were processed for immunostaining.

Statistical analyses. To calculate the mean, SD, and SEM, raw values were exported into Microsoft Excel. At minimum, data from three independent experiments were quantified, and graphs were plotted representing the mean \pm SEM. Statistical significance was determined based on $p$ values obtained using an unpaired, two-tailed Student's $t$ test.

\section{Results}

\section{PMP22 is required for the organization of F-actin at} Schmidt-Lanterman incisures

PMP22 is known to regulate cell shape and membrane expansion (Brancolini et al., 1999; Roux et al., 2005), functions that require changes in the actin cytoskeleton. We assessed the localization of F-actin during postnatal myelination in nerve fibers from WT $\left(\mathrm{PMP} 22^{+/+}\right.$) and PMP22 $2^{-l-}$ mice (Fig. $1 A$ ). In normal nerves, by 2 weeks of postnatal development, F-actin is prominent within intermittently dispersed conical-shaped funnels that are representative of SLIs (Fig. $1 A$, arrowheads), as well as in paranodal myelin loops, periaxonal membranes, and inner and outer mesaxons (Trapp et al., 1989). In contrast to the organized distribution of F-actin at SLIs of WT nerves, samples from agematched PMP22-deficient mice show severely altered F-actin localization across all three ages examined. Notable pathological features include small and irregularly shaped SLIs, perinuclear clusters of F-actin (Fig. 1A, arrows), and intense phalloidin labeling at tomacula (Fig. 1A, circles). Quantification of the number of SLIs per unit length of nerve $(100 \mu \mathrm{m})$ reveals a highly significant decrease in funnel-shaped incisures, while irregular phalloidinpositive actin clusters are increased in nerves of affected mice (Fig. 1B). As an additional analysis of SLI irregularities, we measured the shape of SLIs and determined the length/width index (Yin et al., 2008; Jung et al., 2011). As shown in Figure 1C, there is a significant decrease in the length/width index of SLI in nerves of PMP22-deficient mice. These results indicate that the structured distribution of filamentous actin at SLIs and other noncompacted myelin domains require PMP22.

By immunoblotting, we confirmed the expression of PMP22 in nerves from WT mice and its absence from the transgenic PMP22 ${ }^{-1-}$ samples, which are positive for $\beta$-gal (Fig. $1 D$; Amici et al., 2006). Based on the irregular profile of F-actin in SLIs, we examined the expression of proteins that are found in uncompacted myelin (Fig. 1E). Compared with age-matched WT mice, the levels of MAG, an adhesion molecule that mediates adaxonal contact during early development (Inuzuka et al., 1991), remain elevated at P60 in nerves from PMP22 $2^{-1-}$ mice (Fig. 1E). Similarly, the expression of E-cadherin in WT nerve lysates declines by P60 (Menichella et al., 2001; Crawford et al., 2008), but remains atypically high across all ages in PMP22-deficient samples. Despite these differences in the levels of MAG and E-cadherin, the abundance of total actin is comparable between the two genotypes (Fig. 1E). These data are in agreement with previous studies during the first 3 months of development in this model (Amici et al., 2006), and indicate that the regulation of actin filament organization and the timely expression of uncompact myelin proteins are affected by the absence of PMP22.

\section{The absence of PMP22 has pronounced impact on Schwann cell elongation, lamellipodial morphology, and cell adhesion and migration}

In addition to delayed developmental myelin synthesis, previous studies reported shortened myelin internodes in nerves from PMP22-deficient mice (Neuberg et al., 1999; Amici et al., 2007). Consistent with these reports, the majority of MBP-immunoreactive myelin segments produced by PMP22-deficient Schwann cells are significantly shorter compared with WT cells (Fig. 2A-C). Myelin produced by PMP22-deficient Schwann cells also display pathological features, including beading (Fig. $2 B^{\prime}$ ) and bending (Fig. $2 B^{\prime \prime}$ ) within internodes. Comparison of frequency distribution of MBP-positive myelin segments by length between the genotypes reveals a significantly $\left.{ }^{* * *} p<0.001\right)$ 


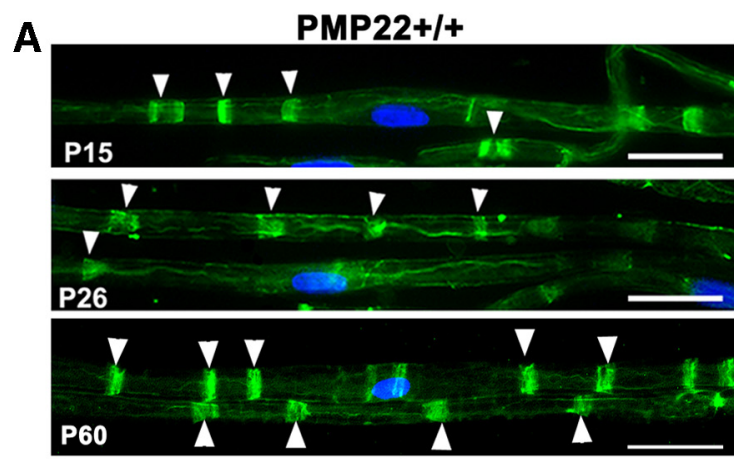

B
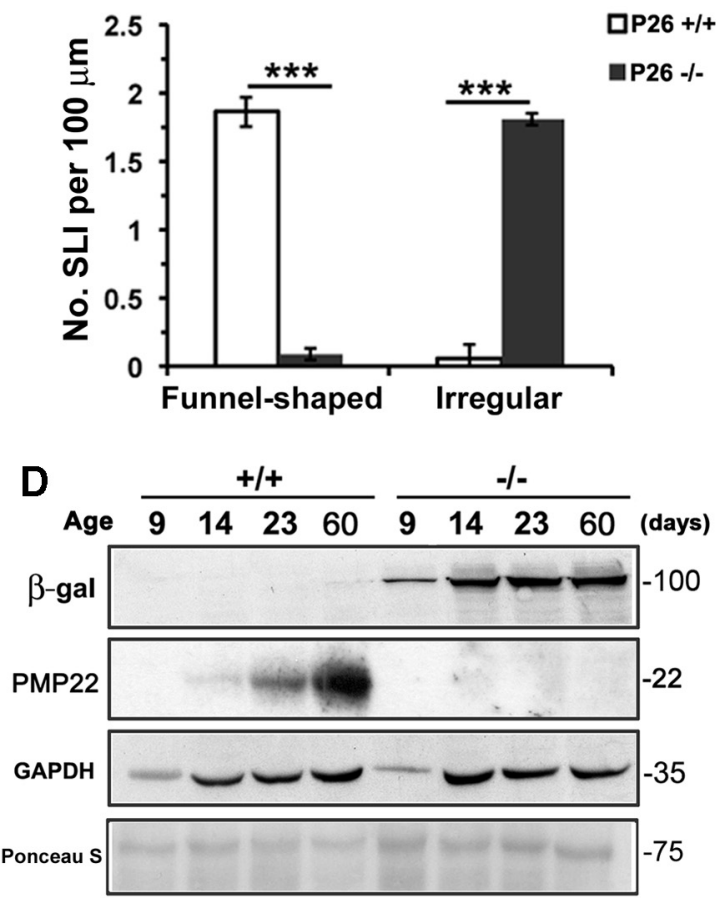

PMP22-/-
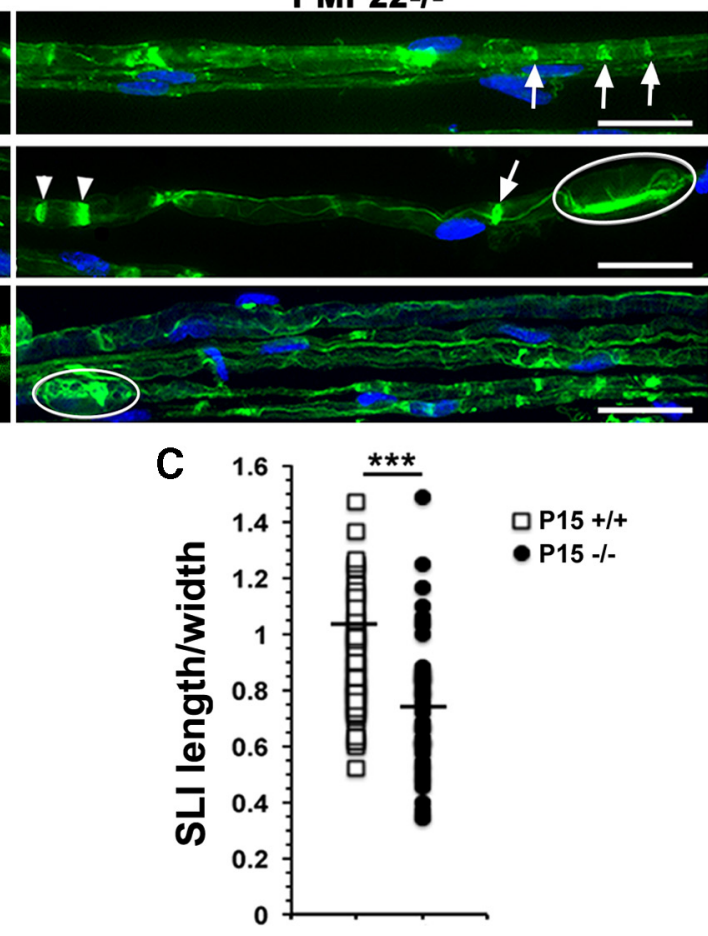

E

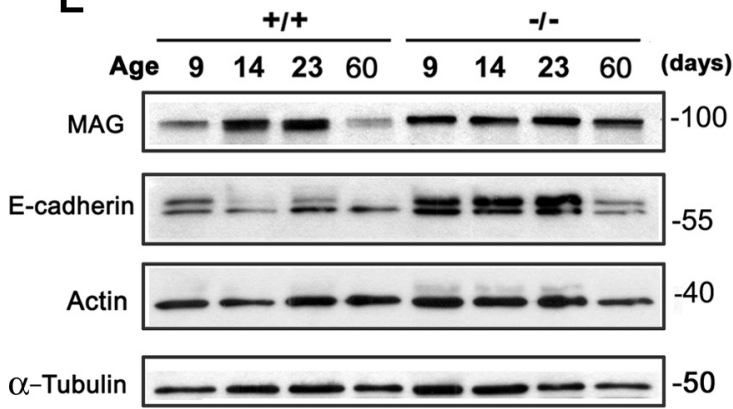

Figure 1. Alterations in F-actin and proteins of Schmidt-Lanterman incisures in the absence of PMP22. A, Sciatic nerves from WT (PMP22 ${ }^{+/+}$) and PMP22 ${ }^{-/-}$mice at the indicated ages were labeled with phalloidin to identify F-actin. Funnel-shaped normal incisures (arrowheads), irregularly shaped incisures (arrows), and tomaculae (circle) are marked. Nuclei are labeled with Hoechst dye (blue). Scale bars, $25 \mu \mathrm{m}$. B, Quantification of funnel-shaped and irregular SLls per unit length of nerve ( $n=5-6$ individual nerve samples per genotype). $\boldsymbol{C}$, Scatter plot of SLI length/width index from P26 sciatic nerves ( $n=5-6$ individual nerve samples per genotype). $\boldsymbol{D}, \boldsymbol{E}$, Sciatic nerve total protein lysates (15 $\mu$ g/lane) were immunoblotted with the indicated antibodies. Ages of the donor tissues are indicated in postnatal days. GAPDH, $\alpha$-tubulin, and Ponceau $S$ stains of the blots are shown as protein-loading controls. Molecular weight is reported in kilodaltons (right).

higher proportion of internodes in the range of $\leq 75 \mu \mathrm{m}$, and a significantly $\left.{ }^{* * *} p<0.001\right)$ smaller proportion $>100 \mu \mathrm{m}$, in cultures from PMP22 $2^{-/-}$mice (Fig. $2 C$ ).

To examine whether the shortened cellular phenotype is inherent to PMP22-deficient glia even in the absence of axonal contact, we analyzed morphological features of nonmyelinating Schwann cells, after immunolabeling with an anti-P75 antibody (Fig. 2D,E). While WT Schwann cells display a polarized and elongated morphology with prominent lamellipodia (Fig. $\left.2 D, D^{\prime}\right)$, cells cultured from PMP22 $2^{-1-}$ mice frequently appear flattened and short (Fig. 2E, $E^{\prime}$ ). Quantification of the cell length along the longest axis (axial length) indicates that the absence of PMP22 causes a shortened phenotype, regardless of the plating substrate of either PL or laminin (Fig. $2 F$ ). We also detected morphological differences in the lamellipodial ruffles, which appear jagged and collapsed in the absence of PMP22 (Fig. 2E'), compared with the smooth and rounded morphology in nearly all WT cells (Fig. 2D').
While it is known that the amount of PMP22 expression increases with myelination, the presence and maturation of the protein in nonmyelinating rat Schwann cells has been documented (Pareek et al., 1997). Similarly, in WT mouse Schwann cells lysates, immunoblotting with anti-PMP22 antibody identifies an $\sim 22 \mathrm{kDa}$ band (Fig. $2 G$, lane C) that shifts to the $18 \mathrm{kDa}$ core peptide upon treatment with $N$-glycosidase (Fig. $2 G$, lane $\mathrm{N})$. In the fully mature and plasma membrane-associated form, PMP22 acquires a complex carbohydrate modification and is resistant to endoH (Pareek et al., 1993). In accord, a fraction of PMP22 in nonmyelinating WT mouse Schwann cells is not cleaved by endoH (Fig. $2 G$, lane $\mathrm{H}$ ), indicating association with the plasma membrane. Together, these results show that in normal mouse Schwann cells PMP22 regulates the elongation and extension of plasma membrane in a cell-autonomous mechanism.

Next, we tested whether the lack of PMP22 influences Schwann cell migration, a function that requires filamentous actin dynamics (Insall and Machesky, 2009). The migratory effi- 

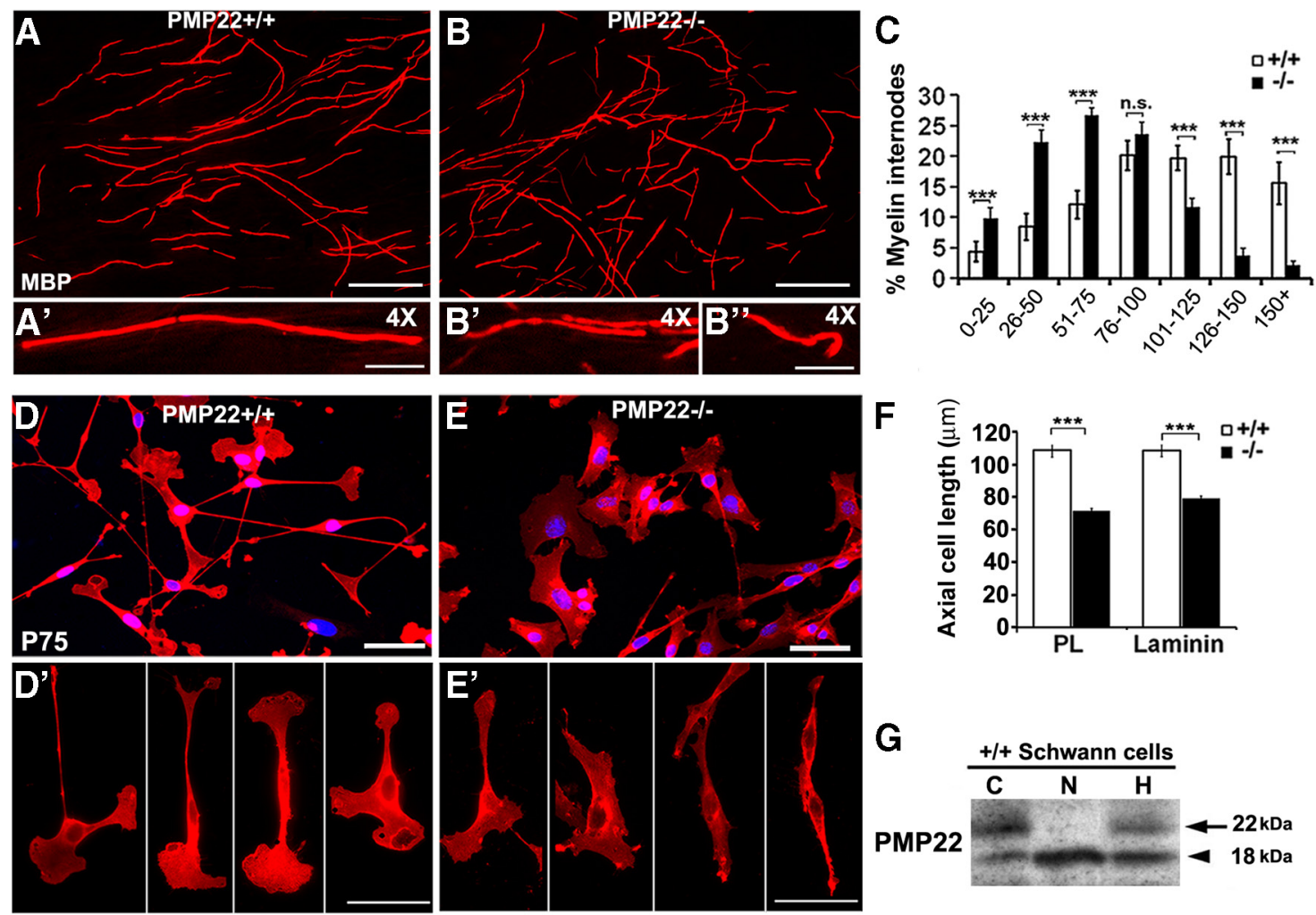

Figure 2. PMP22 augments the elongation of myelinating and nonmyelinating Schwann cells. $A, B$, Representative images of MBP-like immunoreactivity in myelinating DRG explants from WT $\left(\right.$ PMP22 $\left.^{+/+}\right)(\boldsymbol{A})$ and PMP22 ${ }^{-/-}(\boldsymbol{B})$ mice. $\boldsymbol{A}^{\prime}, \boldsymbol{B}^{\prime}, \boldsymbol{B}^{\prime \prime}, 4 \times$ magnification of MBP-positive myelinated internodes. $\boldsymbol{C}$, Frequency distribution of internodes lengths is graphed. Internode lengths were binned into $25 \mu \mathrm{m}$ intervals and graphed as a percentage of the total number of internodes. $\boldsymbol{D}-\boldsymbol{E}^{\prime}$, Morphology of WT (PMP22 ${ }^{+/+}$) and PMP22 ${ }^{-/-}$Schwann cells after immunolabeling with anti-P75 antibody (red). Nuclei were stained with Hoechst dye and are shown in blue. $\boldsymbol{D}^{\prime}-\boldsymbol{E}^{\prime}$, Representative individual WT and PMP22 ${ }^{-I-}$ Schwann cells are shown. $\boldsymbol{F}$, Measurements of axial cell length after anti-P75 immunolabeling and plating on PL or laminin. G, Total protein lysates (30 $\mu$ g/lane) of normal Schwann cells were digested with $N$-glycosidase (N) or endoH (H) and were probed with anti-PMP22 antibody. Lane C contains samples incubated without enzyme. Arrows mark the glycosylated PMP22, while arrowheads point to the deglycosylated PMP22. Molecular mass is reported in kilodaltons. Values represent the mean \pm SEM. ${ }^{* * *} p<0.001$, two-tailed Student's t test. n.s, Not significant. For the quantifications, data were analyzed from three independent cultures. Scale bars: $\boldsymbol{A}, \boldsymbol{B}, 100 \mu \mathrm{m} ; \boldsymbol{D}-\boldsymbol{E}^{\prime}, 20 \mu \mathrm{m}$.

ciency of nonmyelinating Schwann cells was analyzed in the scratch wound assay (Meintanis et al., 2001), which promotes cells to undergo directional movement. After an $8 \mathrm{~h}$ period, PMP22-deficient cells show reduced mobility compared with WT (Fig. $3 A, B$ ). This impairment in migration by PMP22deficient cells is significant for both laminin and fibronectin substrate (Fig. $3 C$ ). As migration by adherent cells requires dynamic assembly and disassembly of adhesive contacts with the extracellular matrix (ECM), we compared the adhesive properties of WT and PMP22-deficient cells. Using BSA or laminin as a substrate, PMP22 ${ }^{-1-}$ Schwann cells adhered $\sim 60 \%$ less to laminin than WT cells, attaching only slightly more to laminin than to BSA (Fig. 3D). This finding supports a role for PMP22 in mediating the interaction of Schwann cells with the ECM, likely through association with the $\alpha 6 \beta 4$ integrin complex (Amici et al., 2006).

In addition to altered adhesion, membrane dynamics at the leading edge may also account for the delayed migration of PMP $22^{-1-}$ Schwann cells. Therefore, we examined lamellipodia morphology after the scratch migration by immunostaining the cultures with an anti-P75 antibody (Fig. 4A,B). While WT cells display many broad, fan-shaped lamellipodia that face the scratch (Fig. 4A, arrows), PMP22 ${ }^{-1-}$ Schwann cells show a $>20 \%$ reduction (mean $\pm \mathrm{SD}, 100 \pm 12$ vs $75 \pm 20 ;{ }^{\star} p<0.05$ ) in properly formed lamellipodia (Fig. $4 B$, arrow). A number of thin, collapsed cell projections are visible at the leading edge of the migrating PMP $22^{-/-}$cultures (Fig. $4 B$, arrowheads). The decrease in lamellipodia ruffles in PMP22 $2^{-1-}$ Schwann cells was con- firmed by double immunostaining with antibodies to actin and the focal adhesion protein vinculin, which links adhesion molecules to the actin cytoskeleton (Mierke, 2009; Fig. 4C,D). The localization of vinculin-like staining is collapsed in lamellipodia of PMP22 $2^{-1-}$ Schwann cells (Fig. 4C), compared with the fanshaped pattern in WT cells (Fig. 4C). We found a similar distribution of F-actin at the lamellipodia of migrating cells, by labeling with phalloidin (Fig. $4 E, F$ ).

As PMP22 was originally identified in fibroblasts (Schneider et al., 1988) and its expression levels are known to affect the morphology of NIH3T3 cells (Fabbretti et al., 1995; Brancolini et al., 1999; Roux et al., 2005), we asked whether the observed migratory deficits of PMP22-deficient Schwann cells would be replicated in MEFs. Consistent with the upregulation of PMP22 transcripts under growth-arrested conditions (Brancolini et al., 1999), $\beta$-gal is expressed in PMP22-deficient MEFs after $24 \mathrm{~h}$ culture in $0.5 \%$ FCS (Fig. $5 A$ ). Within the same cell lysates, the steady-state levels of vinculin and actin are not affected by the absence of PMP22 (Fig. 5A). Next, we assessed the adhesive properties of WT and PMP22 $2^{-1-}$ MEFs on BSA, poly-L-lysine, and fibronectin-coated tissue culture plates. As shown in the quantification of independent experiments, on all three substrata tested, the absence of PMP22 negatively impacts the adherence of the cells (Fig. 5B).

Similar to working with Schwann cells, we used the scratch wound assay to compare the migratory capacity of WT and PMP22 ${ }^{-1-}$ MEF cultures (Fig. $5 C-D^{\prime}$ ). Analogous to the find- 


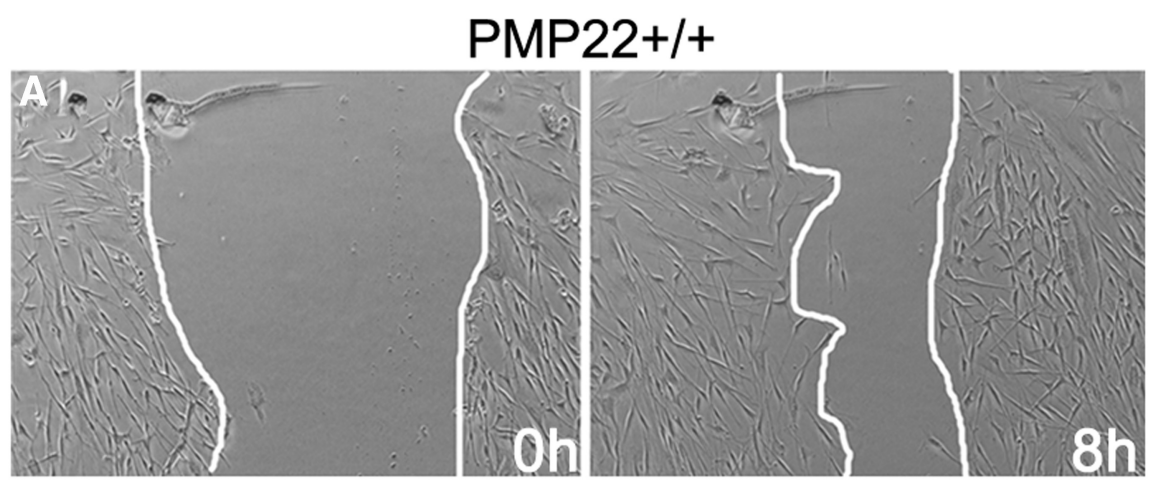

PMP22-/-
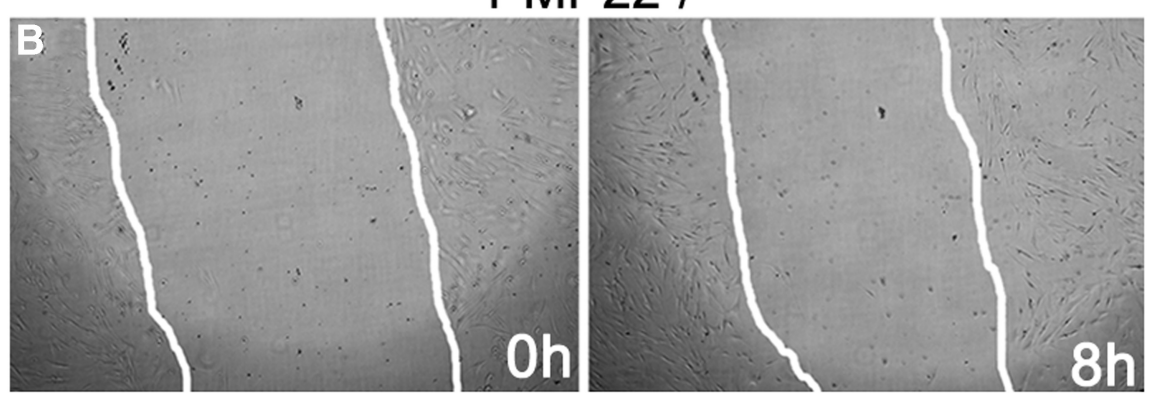

C

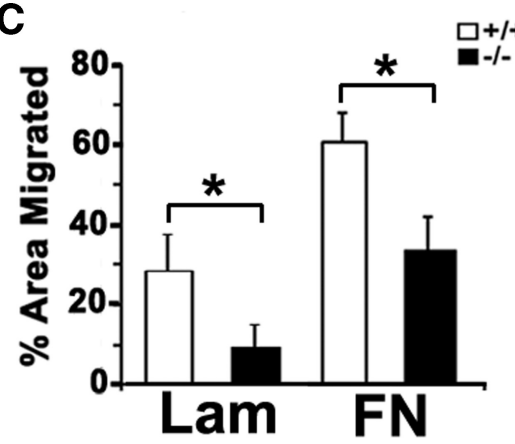

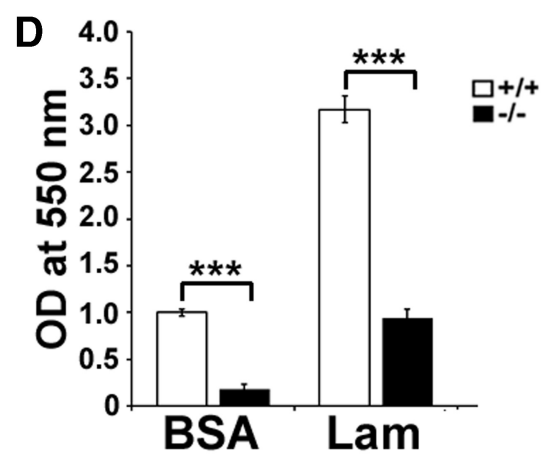

Figure 3. PMP22 regulates Schwann cell migration and adhesion. $\boldsymbol{A}, \boldsymbol{B}$, Representative phase contrast images of WT $\left(\right.$ PMP22 $2^{+/+}$) and PMP22 $2^{-/-}$Schwann cells at 0 and $8 \mathrm{~h}$ postscratch in the wound migration assay. White lines indicate wound boundaries. C, Quantification of area migrated by WT and PMP $22^{-1-}$ cells on laminin (Lam) and on fibronectin (FN). D, Adhesion assay of Schwann cells on BSA or Lam. Data are graphed after optical density (OD) values were normalized to the BSA controls and represent the mean $\pm S D$. The data shown are representative of three to five independent culture experiments. Student's $t$ test: ${ }^{*} p<0.05 ;{ }^{* * *} p<0.001$.

ings in glia (Fig. 3), fibroblasts deficient in PMP22 are impaired in their ability to close the wound, compared with WT cells (Fig. 5C-D'). Quantification of the percentage of the area migrated $8 \mathrm{~h}$ post-scratch wounding reveals that the mobility of PMP22 $2^{-1-}$ fibroblasts on fibronectin-coated plates is $\sim 30 \%$ less than that in WT cells (mean \pm SEM, $52.5 \pm 2.4$ vs $36.6 \pm 2.9 ; p=0.00006$ ). Using phalloidin, we examined the distribution of F-actin at the leading edge of the MEF cultures (Fig. 5E,F). Compared with PMP22 $2^{-1-}$ Schwann cells, both WT and PMP22-deficient MEFs extended fan-shaped filopodia; however, prominent stress fibers are observed in PMP22 $2^{-1-}$ cultures (Fig. $5 F$ ). It is possible that in MEFs the absence of PMP22 interferes with actin remodeling, thereby thwarting the migratory ability of the cells. Together, these results support our hypothesis that PMP22 facilitates basic cellular functions that require dynamic rearrangements of the F-actin cytoskeleton, including cell adhesion and motility.
PMP22 is critical for the establishment of lipid rafts

Actin filaments are known to interact with cholesterol-enriched lipid rafts in oligodendrocytes (Taguchi et al., 2005), as well as in epithelia (Head et al., 2014). Since PMP22 is a known constituent of lipid rafts in peripheral nerve myelin and in transfected HeLa cells (Hasse et al., 2002), we examined the localization of lipid raft proteins in the presence and absence of PMP22 (Fig. 6). In WT nerves, the scaffold protein flotillin-1 is detected along the outer Schwann cell membrane, and is colocalized with F-actin at SLIs (Fig. 6A, arrowheads). In nerves from PMP22 ${ }^{-1-}$ mice, flotillin-1 is similarly identified on the outer glial membrane; however, it is not enriched along the SLIs (Fig. 6B, arrows), where F-actin is detected. Indeed, analyses of independent teased nerve fibers from WT and PMP22-deficient mice reveal a significant decrease in SLIs with surrounding flotillin and a corresponding increase in actin clusters without flotillin in the knock-out samples (Fig. 6C). These results suggest a disruption in the organization of lipid rafts, and associated actin filaments (Fig. 1), in the absence of PMP22.

Next, we analyzed whole-nerve lysates from WT and PMP $22^{-1-}$ mice between the ages of $\mathrm{P} 9$ and $\mathrm{P} 60$ with antibodies to flotillin and ApoE (Fig. 6D). Compared with the steady levels of flotillin-1 in WT nerves, samples from PMP $22^{-/-}$mice show an increase in flotillin-1 expression at P60 (Fig. 6D). As cholesterol is the main lipid component of rafts (Simons and Ikonen, 1997) and cholesterol is critical for myelination (Saher et al., 2005; Saher et al., 2011), we determined the levels of ApoE, a cholesterol transport molecule, within the same nerve lysates. While the level of ApoE in normal nerves diminishes at approximately P23, it drastically increases by 2 months of age in the transgenic samples (Fig. 6D). This observed atypical pattern in ApoE expression is reminiscent of what has been reported in squalene synthase (SQS)-deficient mice (Saher et al., 2009). As ApoE plays a major role in serum lipid metabolism (Davignon et al., 1999; Fazio and Linton, 2005), we analyzed cholesterol, triglyceride, and ApoE levels in the serum of 6-week-old WT and PMP $22^{-1-}$ mice. No significant differences were found between serum cholesterol levels of fasting $\mathrm{PMP} 22^{-1-}(66 \pm 16 \mathrm{mg} / \mathrm{dl})$ and WT $(75 \pm 20 \mathrm{mg} / \mathrm{dl})$ mice. However, levels of serum triglycerides in PMP22 $2^{-1-}$ mice were significantly lower compared with WT mice ( $40 \pm 3$ and $65 \pm 13 \mathrm{mg} / \mathrm{dl}$, respectively; $p<0.01)$. Serum lipoprotein fractionation via FPLC showed that PMP $22^{-/-}$mice carry $35 \pm$ $6 \%$ less triglyceride in their very low-density lipoprotein compared with WT mice. In line with this observation, PMP22 $2^{-1-}$ mice also showed a $36 \%$ reduction in serum ApoE levels $(p<$ $0.05)$ compared with WT mice. These data indicate that the in- 
crease in ApoE in affected nerve samples is due to changes within the nerve tissue, rather than the vasculature.

To examine the cellular source for the elevated ApoE levels detected in the whole-nerve lysates (Fig. 6D), we performed double immunolabeling on nerve sections with anti-ApoE and S-100 $\beta$ antibodies (Fig. $6 E, F$ ). In nerve sections from 4-week-old WT mice, there are few ApoEreactive cells that also colabel with the Schwann cell marker S-100 $\beta$ (Fig. $6 E$, arrows). In comparison, ApoE-reactive, $S$ - $100 \beta$-positive cells are frequent in nerve sections from PMP $22^{-1-}$ mice (Fig. $6 F$, arrows), suggesting an increase in ApoE synthesis by Schwann cells. To further substantiate the increase in ApoE expression in Schwann cells in the absence of PMP22, we performed Western blots on cell lysates and immunostained cultured glia (Fig. 6G-I). As shown in Figure 6G, there is a notable increase in ApoE in whole Schwann cells, as well as MEF lysates, when PMP22 is deleted. The biochemical studies are corroborated by the reactivity of S-100 $\beta$-positive cultured Schwann cells with ApoE antibodies (Fig. $6 H, I)$. In agreement with the Western blots, the intensity of the ApoE-like immunofluorescence is elevated in cells from PMP $22^{-1-}$ mice, compared with WT mice, when the images are acquired with the same exposure settings (Fig. $6 H, I$ ).

To further examine the linkage between the absence of PMP22 and alterations in lipid rafts and cholesterol homeostasis (Fig. 6), we investigated potential changes in raft lipids in $\mathrm{PMP} 22^{-/}$ nerves (Fig. 7). The ganglioside GM1 marker, Ctx- $\beta$ (Heyningen, 1974) shows abundant granular distribution along myelinated fibers in WT nerves (Fig. $7 A, A^{\prime}$ ). In comparison, nerves from $\mathrm{PMP} 22^{-/-}$mice display an overall reduced labeling with Ctx- $\beta$, and some areas of the nerves are nearly devoid of signal (Fig. $7 B, B^{\prime}$, arrows). Concurrently, a subset of PMP $22^{-1-}$ fibers displays clusters of GM1 (Fig. $7 B^{\prime}$, arrowheads), indicating irregularities in the organization of lipid rafts. As a follow-up to the detection of Ctx- $\beta$ clusters in nerves of PMP22-deficient mice (Fig. $7 B, B^{\prime}$ ), we analyzed the distribution of GM1 on the cell surface of nonpermeabilized Schwann cells. In WT cells, Ctx- $\beta$ fluorescence is prominent on the surface, with occasional round patches (Fig. 7C). The distribution of GM1 is notably different on the plasma membrane of PMP22-deficient cells, where the overall fluorescence is reduced, and fewer Ctx- $\beta$ clusters are detected (Fig. 7D).

We also analyzed cholesterol distribution using filipin, a polyene antibiotic that binds specifically to cholesterol (Norman et al., 1972; Lintner and Dyer, 2000). In nerves from WT mice, the distribution of filipin-cholesterol is nearly homogenous, yielding a strong signal along myelinated membranes (Fig. $7 E, E^{\prime}$ ). Reminiscent of the GM1 pattern, in PMP22-deficient nerves, there is an overall reduction in the filipin-cholesterol fluorescence (Fig. $\left.7 F, F^{\prime}\right)$. Concomitantly, in certain areas, we detect clusters of filipin labeling (Fig. $7 D^{\prime}$, arrows), which may suggest altered trafficking of cholesterol in Schwann cells. Therefore, we next examined the distribution of cholesterol in Schwann cells cul- tured from WT and PMP22 $2^{-1-}$ mice (Fig. 7G,H). As filipin permeabilizes the membrane of cells (Norman et al., 1972), this technique detects mostly intracellular stores of cholesterol. In the absence of PMP22, the distribution of cholesterol-containing vesicles appear larger and clustered (Fig. $7 H$, arrows) compared with the smaller, more uniform vesicular pattern in WT cells (Fig. $7 G$ ). Overall, there appears to be a preferential retention of cholesterol within the perinuclear region of the Schwann cell, when PMP22 is absent. To corroborate the apparent reduction in the overall filipin cholesterol labeling in affected nerves and Schwann cells, we quantified filipin-cholesterol intensity using ImageJ (Fig. 7I). As shown in the graphs, in both 3-and 7- to 9-week-old mouse nerves we detect an $\sim 30 \%$ decrease in filipin-cholesterol when PMP22 is absent. In agreement, analyses of total nerve cholesterol using a colorimetric method also detects a statistically significant $32 \pm 4 \%(p<0.01)$ reduction in cholesterol in the nerves of PMP $22^{-1-}$ mice, compared with WT mice. Together, these data indicate that the absence of PMP22 leads to alterations in the distribution of raft lipids and a significant decrease in total nerve cholesterol.

\section{Exogenous cholesterol restores cell length and migration deficits in the absence of PMP22}

To test whether altered levels of lipid raft cholesterol is a contributing factor in PMP22 deficiency-dependent cell elongation and migration defects, we assessed the effects of exogenous cholesterol supplementation on PMP22-null Schwann cells (Fig. 8). Control and PMP22-deficient cultures were maintained in 10\% lipoprotein-deficient FCS before the addition of $20 \mu \mathrm{g} / \mathrm{ml}$ cholesterol, after which axial cell length and migratory capacity were tested. Cell morphology after staining with the plasma membrane 
A

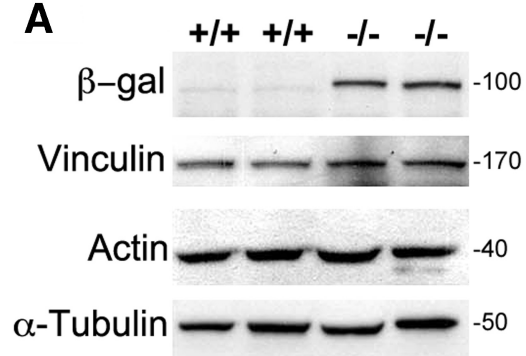

B
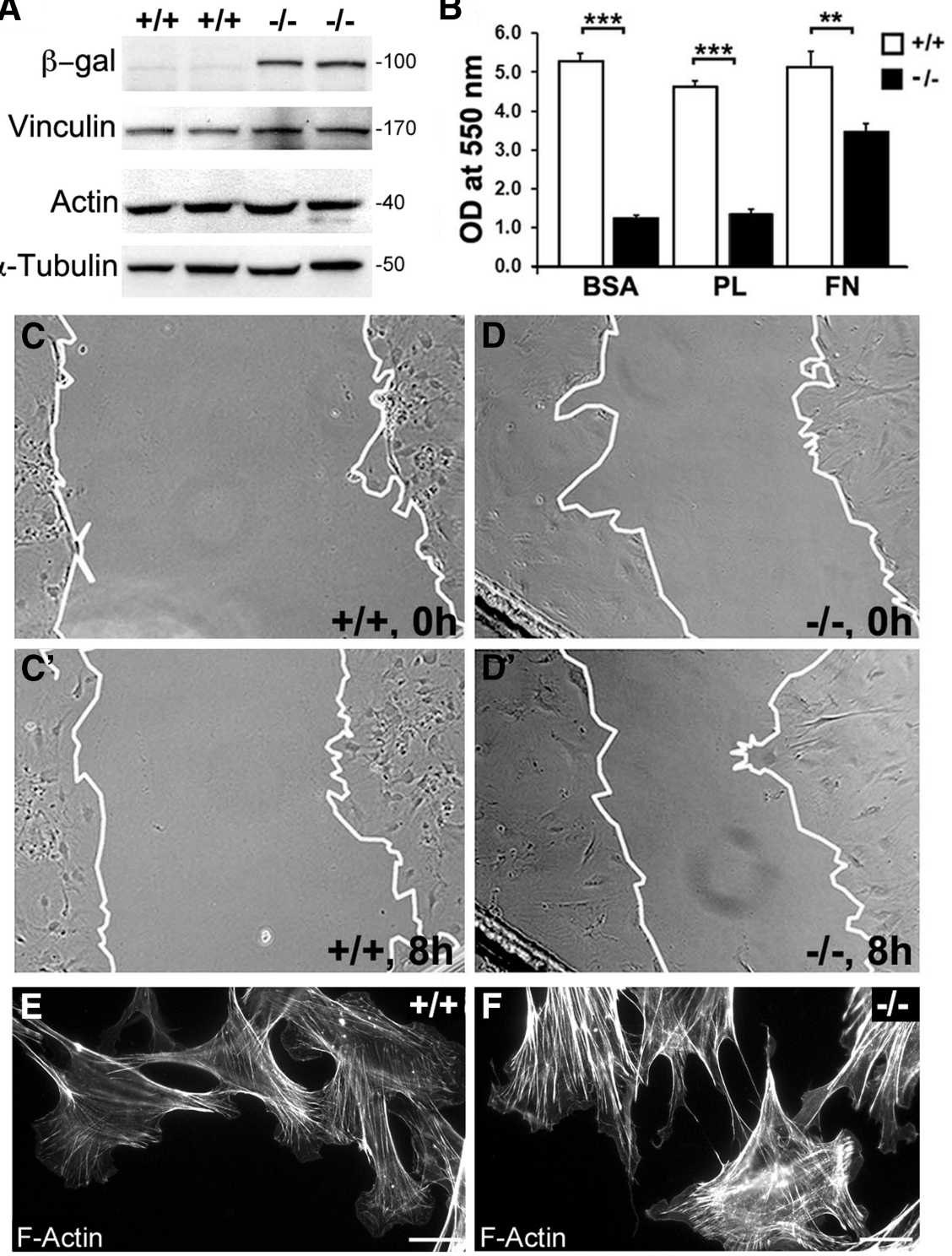

Figure 5. PMP22 is critical for adhesion and migration in fibroblasts. $\boldsymbol{A}$, Total protein extracts (20 $\mu \mathrm{g} /$ lane) from WT (PMP22 $^{+/+}$) and PMP22 $2^{-/-}$fibroblasts were blotted with antibodies against $\beta$-gal, vinculin, and actin. $\alpha$-Tubulin is shown as a protein-loading control. Molecular mass is reported in kilodaltons. $\boldsymbol{B}$, Adhesion assay with WT and PMP22 ${ }^{-1-}$ fibroblasts on BSA, PL, or fibronectin (FN)-coated wells. Values represent the mean \pm SEM. Student's $t$ test: ${ }^{* *} p<0.01$; $^{* * *} p<0.001 . n=3$ independent culture experiments, with duplicate wells per experiment. $\mathbf{C}-\boldsymbol{D}^{\prime}$, Representative phase contrast images of WT and PMP22 ${ }^{-1-}$ fibroblasts at $0 \mathrm{~h}(\boldsymbol{C}, \boldsymbol{D})$ and $8 \mathrm{~h}\left(\boldsymbol{C}^{\prime}, \boldsymbol{D}^{\prime}\right)$ after scratch wounding. The migration front is indicated with a white line. $\boldsymbol{E}$, $\boldsymbol{F}$, F-actin labeling with phalloidin after $8 \mathrm{~h}$ scratch wound migration in WT and PMP22 ${ }^{-1-}$ fibroblasts. At the migration front, PMP22 $2^{-1-}$ cells $(\boldsymbol{F})$ display prominent stress fibers compared with WT controls $(\boldsymbol{E})$. Scale bars: $\boldsymbol{E}, \boldsymbol{F}, 20 \mu \mathrm{m}$.

marker FM-143 reveals no obvious difference between WT and PMP22-deficient cells after cholesterol supplementation (Fig. $8 A$ ). Indeed, quantification of axial cell length confirms that PMP22 $2^{-1-}$ cells significantly extend with cholesterol supplementation, and regain cell length similar to that in WT cells (Fig. $8 B)$. We also performed the scratch-wound migration assay in the absence or presence of $20 \mu \mathrm{g} / \mathrm{ml}$ cholesterol (Fig. $8 C$ ). While migration of PMP22-deficient cells is significantly slower than that of WT cells in the absence of cholesterol, providing an exogenous source of cholesterol increases the overall migration speed of both cell types (WT, ${ }^{* *} p<0.001$; PMP22 $2^{-1-},{ }^{* *} p<0.001$ ). Quantification of data from independent experiments reveals that the percentage area migrated during an $8 \mathrm{~h}$ time period is similar between WT and PMP22-deficient Schwann cells (Fig.

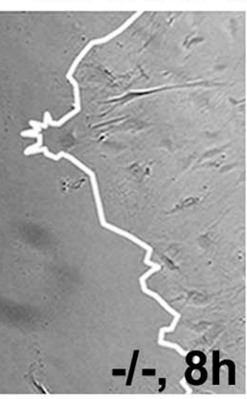

$8 D)$. These results indicate that insufficient cholesterol in the plasma membrane is likely a factor contributing to the functional deficits in migration and cell extension by PMP22-deficient cells.

\section{Discussion}

The results shown in this article demonstrate that in peripheral nerves the absence of PMP22 causes severe disruption in the formation of F-actin-enriched SLIs and associated abnormalities in cholesterolenriched lipid rafts (Fig. 9). We also provide evidence for reduced levels and abnormal localization of cholesterol in PMP22-deficient Schwann cells, an alteration that is associated with impaired cell adhesion, migration, lamellipodia extension, and myelination. With regard to cholesterol trafficking, by examining plasma lipids we ruled out a vascular source for the elevated nerve ApoE in affected mice and found alterations in the lipid balance (Fig. 9, model). How alterations in systemic lipids may impact neuropathy severity is currently unknown and requires further studies in additional neuropathic models. As exogenous supplementation of cholesterol reverses the PMP22-linked defects in cell shape and migration, the results indicate that either directly or through interactions with other glial proteins, PMP22 is crucial for stabilizing cholesterol in the plasma membrane. These findings suggest a novel disease mechanism by which reduced levels of PMP22 at the plasma membrane may lead to demyelination and developmental myelin abnormalities through alterations in the organization and stability of lipid rafts.

The most pronounced cellular defects in the complete absence of PMP22 involve the actin cytoskeletal network (Figs. 1, 2, $3,4,5)$. We found evidence for disruption in the F-actin network in peripheral nerves and in two different culture models, namely, Schwann cells and MEFs. While this finding is novel in the context of myelination, it is a phenotype that has been reported in a number of independent articles. Previous studies have linked the overexpression of PMP22 with alterations in actin-dependent cellular features, such as flattened morphology, altered tight junction permeability, and reduced motility in epithelia (Roux et al., 2005; Zoltewicz et al., 2012). In a number of other cell types, including Schwann cells, Cos7 cells, and NIH3T3 fibroblasts, increased cell spreading, membrane blebbing, and altered plasma membrane dynamics have been reported (Brancolini et al., 1999; Chies et al., 2003; Nobbio et al., 2004). Considering its tetraspan membrane topology, as well as BLAST searches, it is highly unlikely that PMP22 directly binds actin. Nonetheless, based on information from the literature, a number of mechanisms by which PMP22 indirectly affects actin dynamics 

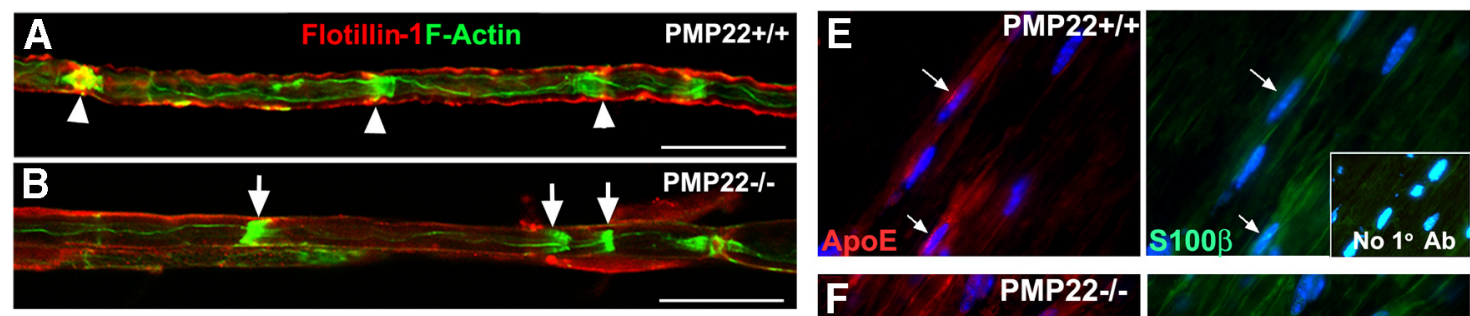

\section{SLls identified by F-Actin}
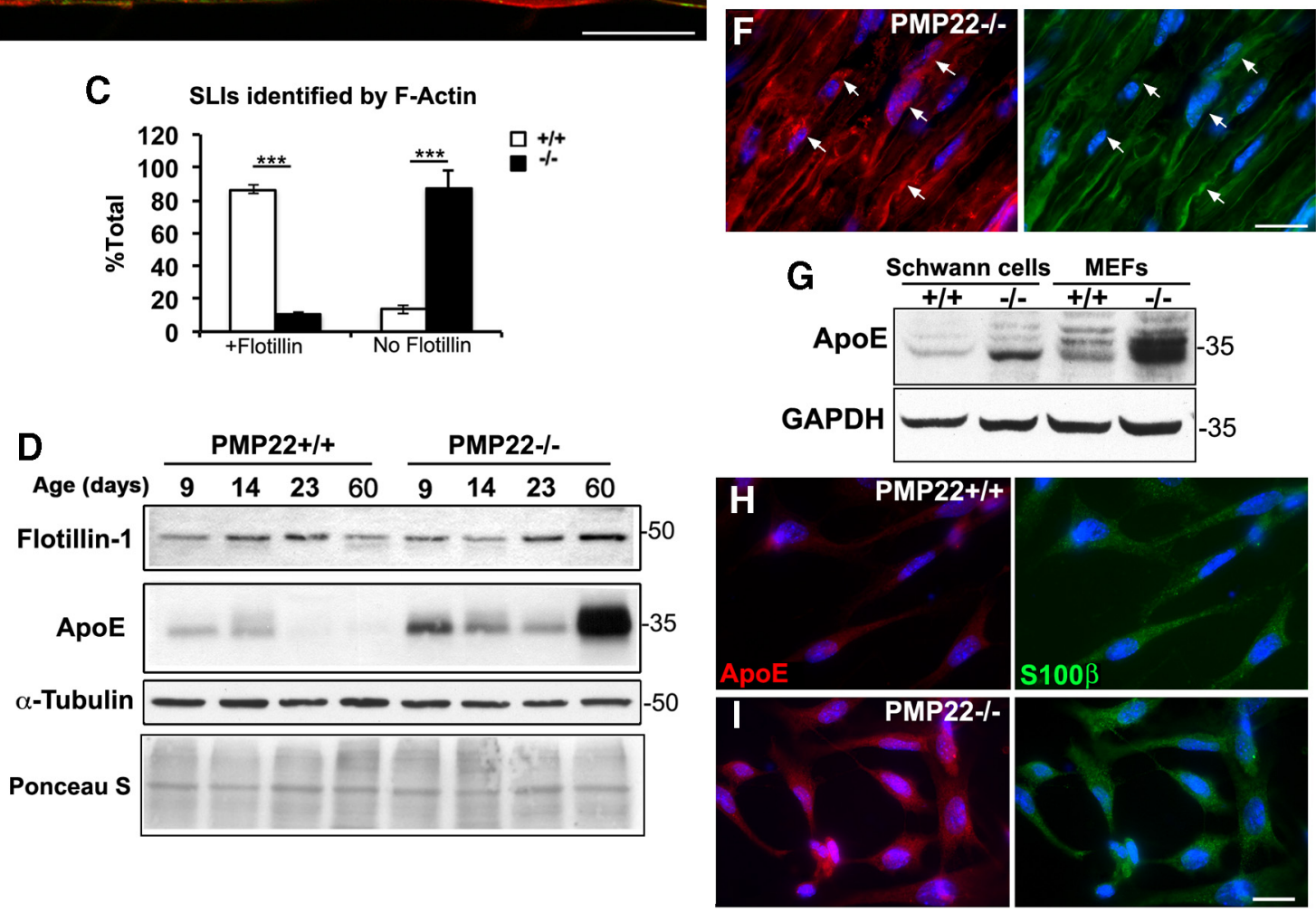

Figure 6. The absence of PMP22 perturbs the localization of the raft protein flotillin- 1 and is associated with an increase in Apo E expression. $A, B$, Sciatic nerves from P15 WT (PMP22 ${ }^{+/+}$) and PMP22 ${ }^{-1-}$ mice were double labeled with phalloidin (green) and anti-flotillin-1 antibody (red). Arrowheads $(\boldsymbol{A})$ indicate flotillin-1 immunoreactivity at F-actin-enriched SLIs, while arrows ( $\boldsymbol{B}$ ) point to SLIs with F-actin-lacking surrounding flotillin-1. Scale bars, $20 \mu \mathrm{m}$. C, Quantification of SLIs flanked by flotillin-1 in nerve samples from WT and PMP22 ${ }^{-1-}$ mice. ${ }^{* * *} p<0.001$, Student's $t$ test. $n=5-6$ nerves per genotype. $D$, Total sciatic nerve lysates (20 $\mu \mathrm{g} / \mathrm{lane})$ from PMP22 ${ }^{+/+}$and PMP22 ${ }^{-/-}$mice at the indicated ages were immunoblotted with antibodies against flotillin-1 and ApoE. $\alpha$-Tubulin and Ponceau S stains of the membrane are shown as controls for protein loading. Molecular weight is reported in kilodaltons (right). $E, F, A p o E$ and S-100 $\beta$ coimmunostaining of WT and PMP22 ${ }^{-1-}$ sciatic nerves are shown. Arrows indicate ApoE-like immunoreactivity within Schwann cells, identified by S-100 $\beta$. Nuclei are shown in blue, after staining with Hoechst dye. Inset in $\boldsymbol{E}$ is an image of a WT nerve section with the anti-mouse secondary antibody alone. $G$, Western blot of ApoE on lysates from WT and PMP22 ${ }^{-1-}$ Schwann cells and MEFs. GAPDH is shown as a protein-loading control. $\boldsymbol{H}, \mathbf{I}$, Double immunolabeling of cultured Schwann cells with ApoE and S-100 $\beta$. Nuclei are shown in blue with Hoechst dye. Scale bar, $20 \mu \mathrm{m}$.

can be proposed. First, using the same animal model as in the current study, we discovered that PMP22 interacts with $\alpha 6 \beta 4$ integrin (Amici et al., 2006), a protein complex with established function in linking laminin to the cytoskeleton (Lee et al., 1992). If the absence of PMP22 destabilizes the expression of $\beta 4$ integrin, alternate integrin subunits with different binding properties may be expressed to compensate (Milner et al., 1997) and, therefore, may be responsible for the altered interactions with laminin and the subcellular actin network. PMP22 could also impact actin dynamics through its palmitoylation, which indeed has a pronounced influence on epithelial cell shape and migration (Zoltewicz et al., 2012). Even though palmitoylation-deficient PMP22 was detected at the plasma membrane, caveolin-enriched microdomains were abnormally clustered compared with cells expressing WT PMP22. PMP22 expression may also influence the Rho GTPases as PMP22 transfection in fibroblasts leads to Rhomediated stress fiber assembly (Brancolini et al., 1999). An additional possibility implicates various scaffold proteins that through direct or indirect interactions with PMP22, or its binding partners such as protein 0 , could affect the stabilization of F-actin.
Myelin has uniquely high cholesterol content and cholesterolenriched membrane microdomains, or lipid rafts, which are functionally important for spatial regulation of structural and signaling proteins. PMP22 associates with lipid rafts in detergentinsoluble fractions (Erne et al., 2002; Hasse et al., 2002), which is consistent with the protein being localized at tight junctions (Notterpek et al., 2001). Lipid rafts serve important roles in the plasma membrane by anchoring signaling complexes, including tight junctions and adherens junctions, which interact with the F-actin cytoskeleton network (Head et al., 2014). Adherens junctions in SLIs contribute to the stabilization of myelin architecture (Fannon et al., 1995) and take an active role in the organization of the actin cytoskeleton (Tricaud et al., 2005). It was recently discovered that reduced PMP22 levels in heterozygous PMP22deficient mice alter the permeability at tight junctions through interaction with MAG and the junctional adhesion molecule-C (Guo et al., 2014). Similarly, changes in tight junction permeability in response to PMP22 overexpression was described in epithelial cells (Roux et al., 2005). Additional support for the connection between lipid rafts and actin filamentous network in peripheral nerve myelin is the previously described interaction 

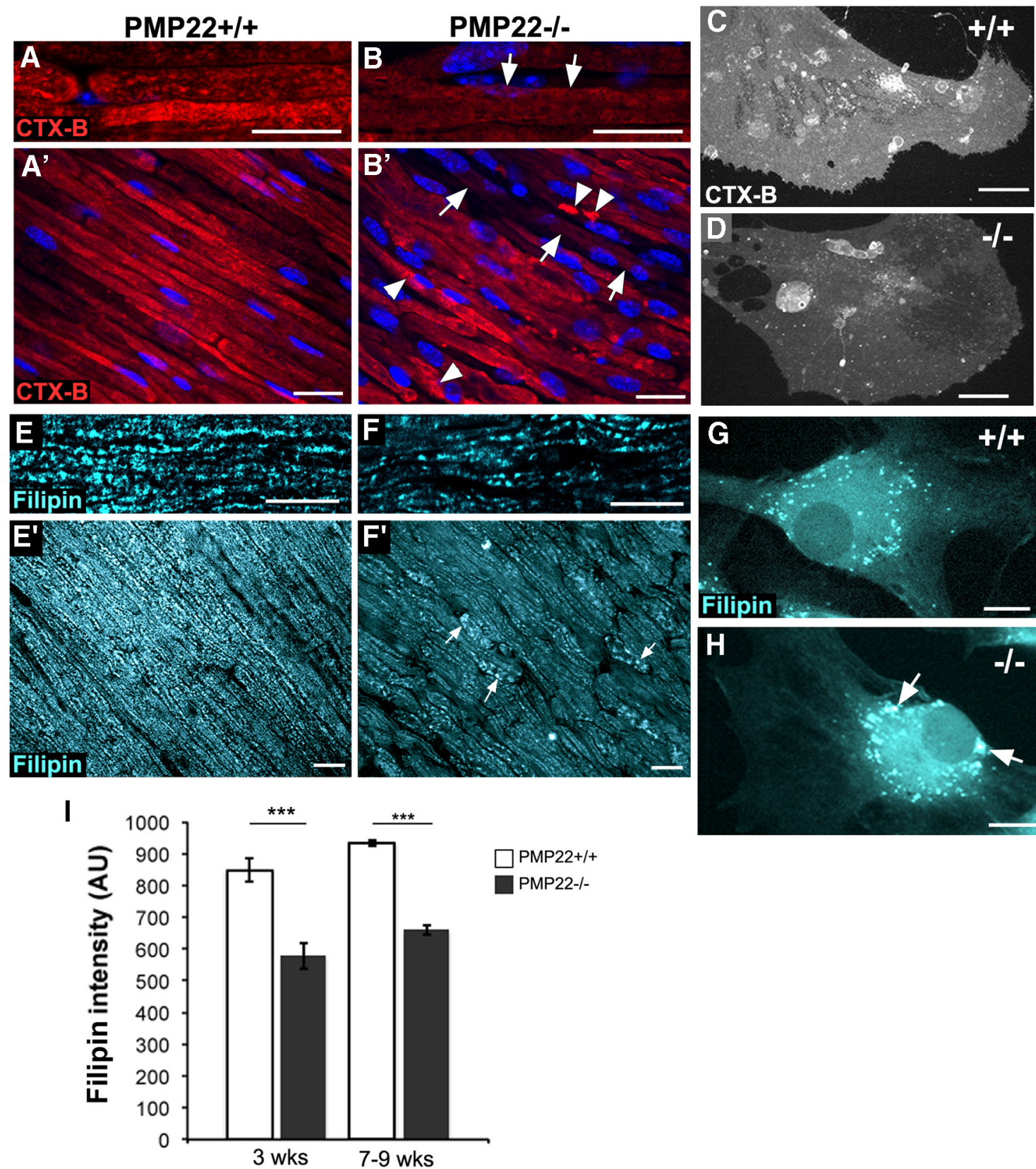

$\square \mathrm{PMP} 22+1+$

PMP22-1-

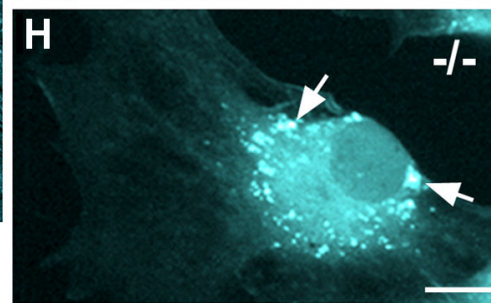

Figure 7. The absence of PMP22 perturbs lipid rafts. $\boldsymbol{A}-\boldsymbol{B}^{\prime}$, Alexa Fluor 594-conjugated (tx- $\beta$ (red) and Hoechst dye (blue) labeling on sciatic nerves from 3- to 4-week-old WT and PMP22 ${ }^{-1-}$ mice. $\boldsymbol{A}^{\prime}-\boldsymbol{B}^{\prime}$, low-magnification images of the nerves shown in $\boldsymbol{A}$ and $\boldsymbol{B}$. In samples from PMP22 ${ }^{-1-}$ mice, arrows $\left(\boldsymbol{B}, \boldsymbol{B}^{\prime}\right)$ indicate reduced $\operatorname{ctx}-\beta$ binding, while arrowheads $\left(\boldsymbol{B}^{\prime}\right)$ mark localized clusters of Ctx- $\beta$. C, $\boldsymbol{D}$, Cell surface labeling of normal ( $\boldsymbol{C}$ ) and PMP22-deficient (D) cultured Schwann cells with Ctx- $\beta$. E- $\boldsymbol{F}^{\prime}$, Visualization of cholesterol-filipin on sciatic nerve sections from 3- to 4-week-old WT and PMP22 ${ }^{-1-}$ mice. Lower-magnification views of the nerves are shown in $\boldsymbol{E}^{\prime}$ and $\boldsymbol{F}^{\prime} . \boldsymbol{G}, \boldsymbol{H}$, Filipin staining of PMP22 ${ }^{+/+}$and PMP22 $2^{-1-}$ Schwann cells. Arrows indicate enlarged clusters of cholesterol in PMP22 ${ }^{-1-}$ Schwann cells. Scale bars: $\boldsymbol{A}-\boldsymbol{D}, 20 \mu \mathrm{m} ; \boldsymbol{E}-\boldsymbol{H}, 10 \mu \mathrm{m}$. I, Quantification of filipin fluorescence intensity in nerves from 3- and 7- to 9-week-old WT and $\mathrm{PMP} 22^{-1-}$ mice is shown. AU, Arbitrary units. ${ }^{* * *} p<0.001$, Student's $t$ test. $n=3$ nerves per genotype.

between lipid rafts and actin filaments in oligodendrocytes (Taguchi et al., 2005). The association between lipid rafts and F-actin in Schwann cells has not been studied in detail; however, when PMP22 is misexpressed, the organization of the F-actin cytoskeleton is disturbed (Kun et al., 2012).

As mentioned above, cholesterol is a known regulator for myelination in the CNS and the PNS (Saher et al., 2011). A number of elegant studies in mice show that when cholesterol synthesis is diminished, oligodendrocytes as well as Schwann cells are unable to form normal myelin (Saher et al., 2005, 2011). In the CNS, it is also known that proteolipid protein (PLP), a critical tetraspan myelin constituent in oligodendrocytes, directly binds choles- terol (Werner et al., 2013). Therefore, it is plausible that based on the structural similarities between PMP22 and PLP, in Schwann cells PMP22 binds cholesterol in the plasma membrane. In support of this hypothesis, PMP22 is an extremely hydrophobic tetraspan protein (Sedzik et al., 2002) that contains one highly conserved cholesterol recognition/interaction amino acid consensus (CRAC) motif within the fourth transmembrane domain (Sedzik et al., 2013). The similarities in abnormalities between PMP $22^{-1-}$ and cholesterol-deficient mice during early postnatal development, such as delayed myelination and reduction in compact myelin proteins (Saher et al., 2005; Amici et al., 2006), support a role for PMP22 in sequestering cholesterol in myelin. 


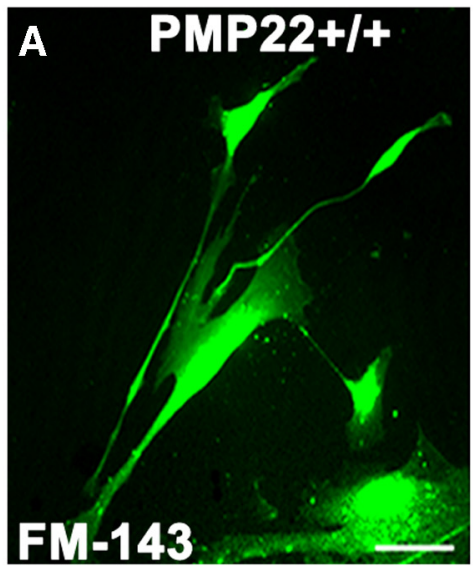

PMP22+/+
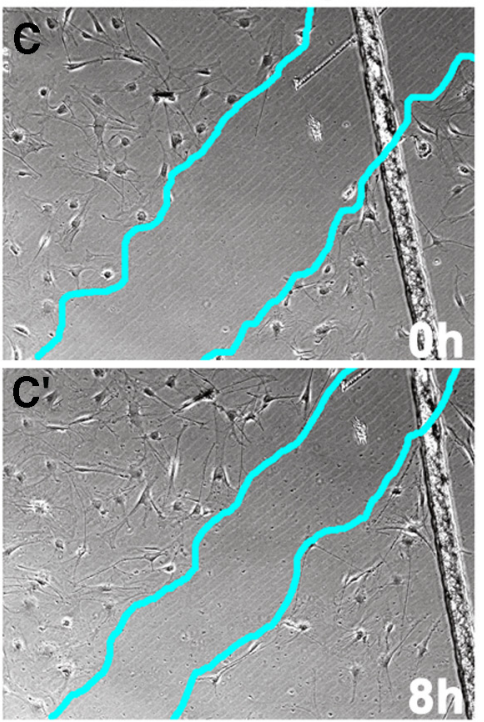

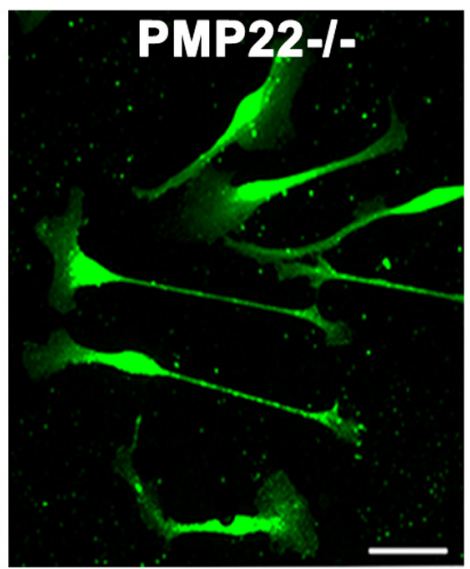

PMP22-/-
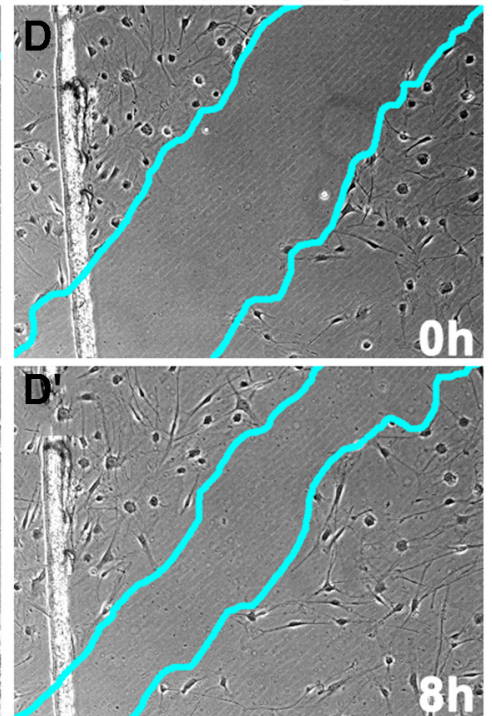

B

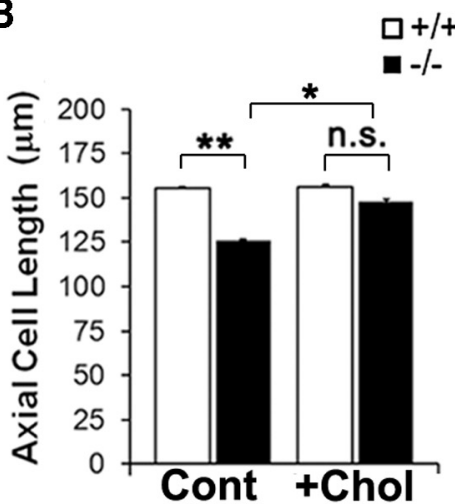

Figure 8. The addition of cholesterol rescues the migration and morphology defects of PMP22-deficient Schwann cells. A, PMP22 ${ }^{+/+}$and PMP22 ${ }^{-/-}$Schwann cells labeled with FM143 after the addition of $20 \mu \mathrm{g} / \mathrm{ml}$ cholesterol for $24 \mathrm{~h}$. Scale bars, $10 \mu \mathrm{m}$. $\boldsymbol{B}$, Axial cell length measured in normal and PMP22 $2^{-/-}$Schwann cells in the presence of cholesterol (+ Chol). $\boldsymbol{C}, \boldsymbol{D}$, Representative $10 \times$ phase contrast images of control (Cont) PMP22 ${ }^{+/+}(\boldsymbol{C})$ and PMP22 ${ }^{-1-}$ Schwann cells (D) before and after $8 \mathrm{~h}$ of migration in the presence of $20 \mu \mathrm{g} / \mathrm{ml}$ cholesterol. The migration front is shown as blue lines. $\boldsymbol{E}$, Quantification of the percentage of the area migrated in the absence or presence of exogenous cholesterol. $\boldsymbol{B}, \boldsymbol{E}$, Values represent the mean $\pm \mathbf{S E M}$; ${ }^{*} p<0.05$; ${ }^{* *} p<0.01$; ${ }^{* * *} p<0.001$; n.S., not significant; two-tailed Student's $t$ test. Data were obtained from two to three independent cell culture experiments.
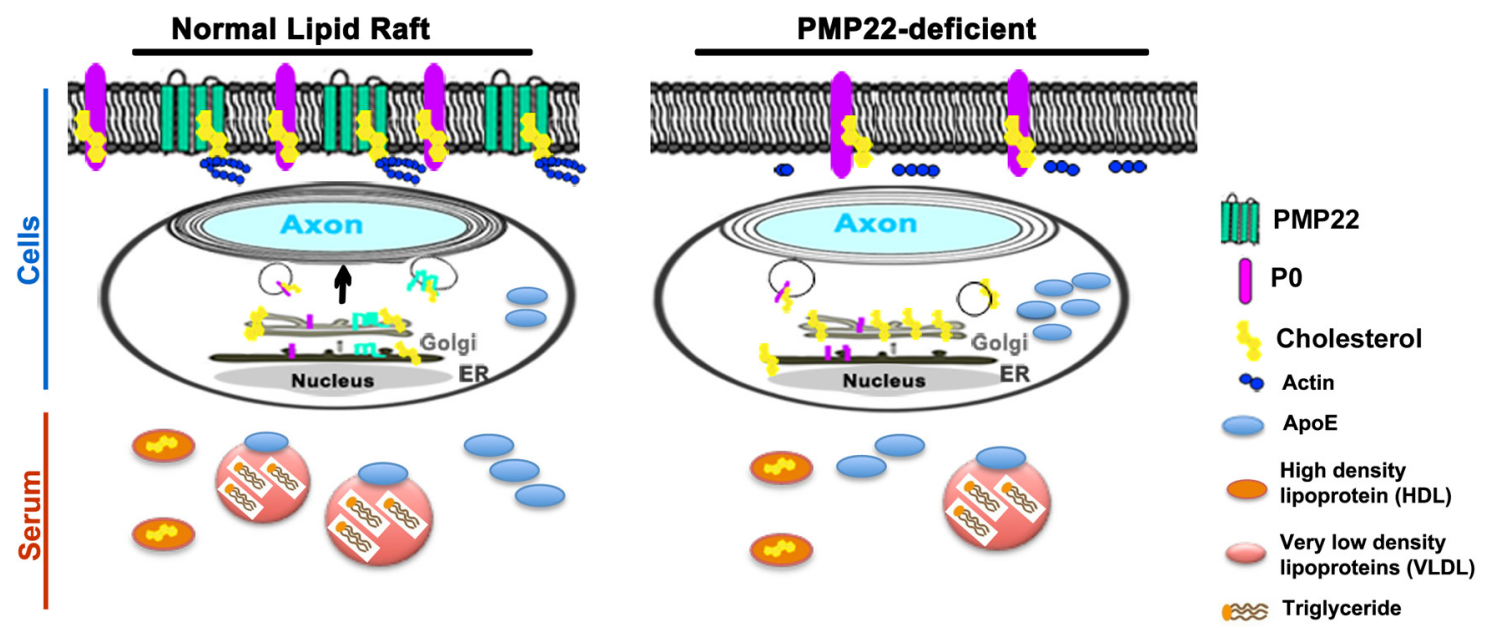

Figure 9. Model of how the absence of PMP22 leads to alterations in the localization of lipid raft-associated filamentous actin and perturbation in cholesterol homeostasis. In the normal nerve, lipid rafts are enriched in cholesterol, and contain PMP22 and protein 0 (PO). Filamentous actin, comprising SLIs, are anchored at lipid rafts. Levels of cholesterol and the cholesterol-binding protein ApoE are low within myelinated Schwann cells. In the absence of PMP22, the nerves are depleted in cholesterol, while ApoE expression is elevated within Schwann cells. Vascular plasma cholesterol levels are stable, while serum ApoE levels are reduced. In the absence of PMP22, the lipid balance of the nerve-vascular unit is altered. 
Finally, there are a number of early reports that described lipid abnormalities in Trembler and Trembler J mice (LarrouquereRégnier et al., 1979; Bourre et al., 1984, 1989), which were later shown to carry mutations in PMP22 (Suter et al., 1992a,b). While myelin abnormalities likely involve alterations in the lipid content of nerves in general, the discovery of specific delays in cholesterol buildup in the Trembler nerve supports the idea that PMP22 is critical for sequestering cholesterol in myelin.

The functional deficits of elongation and migration in PMP22deficient Schwann cells that are restored upon the addition of exogenous cholesterol may reflect a secondary impairment in cholesterol biosynthesis or transport. The pronounced upregulation of ApoE in nerves from PMP22 $2^{-1-}$ mice (Fig. $6 G$ ) may suggest that, in the absence of PMP22, the Schwann cells are more dependent on the uptake of cholesterol from neighboring cells, as was observed in the SQS-deficient model (Saher et al., 2011). The high levels of ApoE in affected nerves did not originate from the circulation, as PMP22 $2^{-1-}$ mice actually exhibited lower serum triglycerides and ApoE levels compared with WT mice. In support of an intracellular cholesterol transport defect, we detected lower levels of total cholesterol and reduced intensity of filipin-cholesterol on the plasma membrane of the mutant cells, while clumps of cholesterol were visible in the perinuclear region (Fig. 7H). How PMP22 expression specifically affects the transport and/or membrane association of cholesterol will require further studies as a number of Schwann cell proteins, including protein 0 contain CRAC motifs (Sedzik et al., 2002). PMP22 is known to interact with protein 0 , whose export from the endoplasmic reticulum is dependent on cholesterol (Saher et al., 2009, 2011). Therefore, it is possible that the interaction between PMP22 and protein 0 is required for fully functional cholesterol transport.

The current study provides the rationale for alternative approaches in modulating myelination and myelin stability in PMP22-linked neuropathies through diet. While exogenous supplementation with lipids will not correct the genetic abnormality in PMP22 neuropathies, it may be effective in slowing disease progression. In support of such an approach is the improved phenotype of PLP-overexpressing transgenic mice, in which feeding a cholesterolenriched diet prevented disease progression and supported myelin membrane expansion (Saher et al., 2012). It is conceivable that effective therapies for hereditary neuropathies will require a combinatorial therapy that will target the intracellular abnormalities in protein homeostasis and the associated pathology due to reduced levels of PMP22 in the plasma membrane.

\section{References}

Abramoff MD, Magalhães PJ, Ram SJ (2004) Image processing with ImageJ. Biophotonics Int 11:36.

Adlkofer K, Martini R, Aguzzi A, Zielasek J, Toyka KV, Suter U (1995) Hypermyelination and demyelinating peripheral neuropathy in Pmp22deficient mice. Nat Genet 11:274-280. CrossRef Medline

Amici SA, Dunn WA Jr, Murphy AJ, Adams NC, Gale NW, Valenzuela DM, Yancopoulos GD, Notterpek L (2006) Peripheral myelin protein 22 is in complex with $\alpha 6 \beta 4$ integrin, and its absence alters the Schwann cell basal lamina. J Neurosci 26:1179-1189. CrossRef Medline

Amici SA, Dunn WA Jr, Notterpek L (2007) Developmental abnormalities in the nerves of peripheral myelin protein 22-deficient mice. J Neurosci Res 85:238-249. CrossRef Medline

Aumailley M, Mann K, von der Mark H, Timpl R (1989) Cell attachment properties of collagen type VI and Arg-Gly-Asp dependent binding to its alpha 2(VI) and alpha 3(VI) chains. Exp Cell Res 181:463-474. CrossRef Medline

Bourre JM, Dumont O, Gumpel M, Cassagne C (1984) Alteration of sulfatide synthesis in control and Trembler mice during Wallerian degeneration and remyelination. Neurochem Pathol 2:153-161. CrossRef Medline
Bourre JM, Clément M, Gérard D, Chaudiére J (1989) Alterations of cholesterol synthesis precursors (7-dehydrocholesterol, 7-dehydrodesmosterol, desmosterol) in dysmyelinating neurological mutant mouse (quaking, shiverer and trembler) in the PNS and the CNS. Biochim Biophys Acta 1004:387-390. CrossRef Medline

Brancolini C, Marzinotto S, Edomi P, Agostoni E, Fiorentini C, Müller HW, Schneider C (1999) Rho-dependent regulation of cell spreading by the tetraspan membrane protein Gas3/PMP22. Mol Biol Cell 10:2441-2459. CrossRef Medline

Brancolini C, Edomi P, Marzinotto S, Schneider C (2000) Exposure at the cell surface is required for gas3/PMP22 To regulate both cell death and cell spreading: implication for the Charcot-Marie-Tooth type $1 \mathrm{~A}$ and Dejerine-Sottas diseases. Mol Biol Cell 11:2901-2914. CrossRef Medline

Chies R, Nobbio L, Edomi P, Schenone A, Schneider C, Brancolini C (2003) Alterations in the Arf6-regulated plasma membrane endosomal recycling pathway in cells overexpressing the tetraspan protein Gas3/PMP22. J Cell Sci 116:987-999. CrossRef Medline

Crawford AT, Desai D, Gokina P, Basak S, Kim HA (2008) E-cadherin expression in postnatal Schwann cells is regulated by the cAMP-dependent protein kinase a pathway. Glia 56:1637-1647. CrossRef Medline

Davignon J, Cohn JS, Mabile L, Bernier L (1999) Apolipoprotein E and atherosclerosis: insight from animal and human studies. Clin Chim Acta 286:115-143. CrossRef Medline

Erne B, Sansano S, Frank M, Schaeren-Wiemers N (2002) Rafts in adult peripheral nerve myelin contain major structural myelin proteins and myelin and lymphocyte protein (MAL) and CD59 as specific markers. J Neurochem 82:550-562. CrossRef Medline

Fabbretti E, Edomi P, Brancolini C, Schneider C (1995) Apoptotic phenotype induced by overexpression of wild-type gas3/PMP22: its relation to the demyelinating peripheral neuropathy CMT1A. Genes Dev 9:18461856. CrossRef Medline

Fannon AM, Sherman DL, Ilyina-Gragerova G, Brophy PJ, Friedrich VL Jr, Colman DR (1995) Novel E-cadherin-mediated adhesion in peripheral nerve: Schwann cell architecture is stabilized by autotypic adherens junctions. J Cell Biol 129:189-202. CrossRef Medline

Fazio S, Linton MF (2005) Interplay between apolipoprotein E and scavenger receptor class B type I controls coronary atherosclerosis and lifespan in the mouse. Circulation 111:3349-3351. CrossRef Medline

Fortun J, Verrier JD, Go JC, Madorsky I, Dunn WA, Notterpek L (2007) The formation of peripheral myelin protein 22 aggregates is hindered by the enhancement of autophagy and expression of cytoplasmic chaperones. Neurobiol Dis 25:252-265. CrossRef Medline

Guo J, Wang L, Zhang Y, Wu J, Arpag S, Hu B, Imhof BA, Tian X, Carter BD, Suter U, Li J (2014) Abnormal junctions and permeability of myelin in PMP22-deficient nerves. Ann Neurol 75:255-265. CrossRef Medline

Hasse B, Bosse F, Müller HW (2002) Proteins of peripheral myelin are associated with glycosphingolipid/cholesterol-enriched membranes. J Neurosci Res 69:227-232. CrossRef Medline

Head BP, Patel HH, Insel PA (2014) Interaction of membrane/lipid rafts with the cytoskeleton: impact on signaling and function: membrane/lipid rafts, mediators of cytoskeletal arrangement and cell signaling. Biochim Biophys Acta 1838:532-545. CrossRef Medline

Heyningen S Van (1974) Cholera toxin: interaction of subunits with ganglioside GM1. Science 183:656-657. CrossRef Medline

Insall RH, Machesky LM (2009) Actin dynamics at the leading edge: from simple machinery to complex networks. Dev Cell 17:310-322. CrossRef Medline

Inuzuka T, Fujita N, Sato S, Baba H, Nakano R, Ishiguro H, Miyatake T (1991) Expression of the large myelin-associated glycoprotein isoform during the development in the mouse peripheral nervous system. Brain Res 562:173-175. CrossRef Medline

Jessen KR, Mirsky R (2005) The origin and development of glial cells in peripheral nerves. Nat Rev Neurosci 6:671-682. CrossRef Medline

Jung J, Cai W, Lee HK, Pellegatta M, Shin YK, Jang SY, Suh DJ, Wrabetz L, Feltri ML, Park HT (2011) Actin polymerization is essential for myelin sheath fragmentation during Wallerian degeneration. J Neurosci 31: 2009-2015. CrossRef Medline

Kun A, Canclini L, Rosso G, Bresque M, Romeo C, Hanusz A, Cal K, Calliari A, Sotelo Silveira J, Sotelo JR (2012) F-actin distribution at nodes of Ranvier and Schmidt-Lanterman incisures in mammalian sciatic nerves. Cytoskeleton 69:486-495. CrossRef Medline

Larrouquere-Régnier S, Boiron F, Darriet D, Cassagne C, Bourre JM (1979) 
Lipid composition of sciatic nerve from dysmyelinating trembler mouse. Neurosci Lett 15:135-139. CrossRef Medline

Lee EC, Lotz MM, Steele GD Jr, Mercurio AM (1992) The integrin alpha 6 beta 4 is a laminin receptor. J Cell Biol 117:671-678. CrossRef Medline

Lee S, Ashizawa AT, Kim KS, Falk DJ, Notterpek L (2013) Liposomes to target peripheral neurons and Schwann cells. PLoS One 8:e78724. CrossRef Medline

Li J, Parker B, Martyn C, Natarajan C, Guo J (2013) The PMP22 gene and its related diseases. Mol Neurobiol 47:673-698. CrossRef Medline

Linder ME, Deschenes RJ (2007) Palmitoylation: policing protein stability and traffic. Nat Rev Mol Cell Biol 8:74-84. CrossRef Medline

Lintner RN, Dyer CA (2000) Redistribution of cholesterol in oligodendrocyte membrane sheets after activation of distinct signal transduction pathways. J Neurosci Res 60:437-449. CrossRef Medline

Meintanis S, Thomaidou D, Jessen KR, Mirsky R, Matsas R (2001) The neuron-glia signal beta-neuregulin promotes Schwann cell motility via the MAPK pathway. Glia 34:39-51. CrossRef Medline

Menichella DM, Arroyo EJ, Awatramani R, Xu T, Baron P, Vallat JM, Balsamo J, Lilien J, Scarlato G, Kamholz J, Scherer SS, Shy ME (2001) Protein zero is necessary for E-cadherin-mediated adherens junction formation in Schwann cells. Mol Cell Neurosci 18:606-618. CrossRef Medline

Mierke CT (2009) The role of vinculin in the regulation of the mechanical properties of cells. Cell Biochem Biophys 53:115-126. CrossRef Medline

Milner R, Wilby M, Nishimura S, Boylen K, Edwards G, Fawcett J, Streuli C, Pytela R, ffrench-Constant C (1997) Division of labor of Schwann cell integrins during migration on peripheral nerve extracellular matrix ligands. Dev Biol 185:215-228. CrossRef Medline

Montani L, Buerki-Thurnherr T, de Faria JP, Pereira JA, Dias NG, Fernandes R, Gonçalves AF, Braun A, Benninger Y, Böttcher RT, Costell M, Nave KA, Franklin RJ, Meijer D, Suter U, Relvas JB (2014) Profilin 1 is required for peripheral nervous system myelination. Development 141: 1553-1561. CrossRef Medline

Neuberg DH, Sancho S, Suter U (1999) Altered molecular architecture of peripheral nerves in mice lacking the peripheral myelin protein 22 or connexin32. J Neurosci Res 58:612-623. CrossRef Medline

Nobbio L, Vigo T, Abbruzzese M, Levi G, Brancolini C, Mantero S, Grandis M, Benedetti L, Mancardi G, Schenone A (2004) Impairment of PMP22 transgenic Schwann cells differentiation in culture: implications for Charcot-Marie-Tooth type 1A disease. Neurobiol Dis 16:263-273. CrossRef Medline

Norman AW, Demel RA, de Kruyff B, van Deenen LL (1972) Studies on the biological properties of polyene antibiotics. Evidence for the direct interaction of filipin with cholesterol. J Biol Chem 247:1918-1929. Medline

Notterpek L, Roux KJ, Amici SA, Yazdanpour A, Rahner C, Fletcher BS (2001) Peripheral myelin protein 22 is a constituent of intercellular junctions in epithelia. Proc Natl Acad Sci U S A 98:14404-14409. CrossRef Medline

Pareek S, Suter U, Snipes GJ, Welcher AA, Shooter EM, Murphy RA (1993) Detection and processing of peripheral myelin protein PMP22 in cultured Schwann cells. J Biol Chem 268:10372-10379. Medline

Pareek S, Notterpek L, Snipes GJ, Naef R, Sossin W, Laliberté J, Iacampo S, Suter U, Shooter EM, Murphy RA (1997) Neurons promote the translocation of peripheral myelin protein 22 into myelin. J Neurosci 17:77547762. Medline

Petr T, Smíd V, Smídová J, Hůlková H, Jirkovská M, Elleder M, Muchová L, Vitek L, Smíd F (2010) Histochemical detection of GM1 ganglioside using cholera toxin-B subunit. Evaluation of critical factors optimal for in situ detection with special emphasis to acetone pre-extraction. Eur J Histochem 54:e23. Medline

Rangaraju S, Madorsky I, Pileggi JG, Kamal A, Notterpek L (2008) Pharmacological induction of the heat shock response improves myelination in a neuropathic model. Neurobiol Dis 32:105-115. CrossRef Medline

Rangaraju S, Verrier JD, Madorsky I, Nicks J, Dunn WA Jr, Notterpek L (2010) Rapamycin activates autophagy and improves myelination in explant cultures from neuropathic mice. J Neurosci 30:11388-11397. CrossRef Medline

Roux KJ, Amici SA, Fletcher BS, Notterpek L (2005) Modulation of epithelial morphology, monolayer permeability, and cell migration by growth arrest specific 3/peripheral myelin protein 22. Mol Biol Cell 16:11421151. CrossRef Medline

Saher G, Brügger B, Lappe-Siefke C, Möbius W, Tozawa R, Wehr MC, Wie- land F, Ishibashi S, Nave KA (2005) High cholesterol level is essential for myelin membrane growth. Nat Neurosci 8:468-475. CrossRef Medline

Saher G, Quintes S, Möbius W, Wehr MC, Krämer-Albers EM, Brügger B, Nave KA (2009) Cholesterol regulates the endoplasmic reticulum exit of the major membrane protein $\mathrm{P} 0$ required for peripheral myelin compaction. J Neurosci 29:6094-6104. CrossRef Medline

Saher G, Quintes S, Nave KA (2011) Cholesterol: a novel regulatory role in myelin formation. Neuroscientist 17:79-93. CrossRef Medline

Saher G, Rudolphi F, Corthals K, Ruhwedel T, Schmidt KF, Löwel S, Dibaj P, Barrette B, Möbius W, Nave KA (2012) Therapy of PelizaeusMerzbacher disease in mice by feeding a cholesterol-enriched diet. Nat Med 18:1130-1135. CrossRef Medline

Saporta MA, Katona I, Zhang X, Roper HP, McClelland L, Macdonald F, Brueton L, Blake J, Suter U, Reilly MM, Shy ME, Li J (2011) Neuropathy in a human without the PMP22 gene. Arch Neurol 68:814-821. CrossRef Medline

Schneider C, King RM, Philipson L (1988) Genes specifically expressed at growth arrest of mammalian cells. Cell 54:787-793. CrossRef Medline

Sedzik J, Uyemura K, Tsukihara T (2002) Towards crystallization of hydrophobic myelin glycoproteins: P0 and PASII/PMP22. Protein Expr Purif 26:368-377. CrossRef Medline

Sedzik J, Jastrzebski JP, Ikenaka K (2013) Sequence motifs of myelin membrane proteins: towards the molecular basis of diseases. J Neurosci Res 91:479-493. CrossRef Medline

Simons K, Ikonen E (1997) Functional rafts in cell membranes. Nature 387: 569-572. CrossRef Medline

Strauss K, Goebel C, Runz H, Möbius W, Weiss S, Feussner I, Simons M, Schneider A (2010) Exosome secretion ameliorates lysosomal storage of cholesterol in Niemann-Pick type C disease. J Biol Chem 285:2627926288. CrossRef Medline

Suter U, Welcher AA, Ozcelik T, Snipes GJ, Kosaras B, Francke U, BillingsGagliardi S, Sidman RL, Shooter EM (1992a) Trembler mouse carries a point mutation in a myelin gene. Nature 356:241-244. CrossRef Medline

Suter U, Moskow JJ, Welcher AA, Snipes GJ, Kosaras B, Sidman RL, Buchberg AM, Shooter EM (1992b) A leucine-to-proline mutation in the putative first transmembrane domain of the $22-\mathrm{kDa}$ peripheral myelin protein in the trembler-J mouse. Proc Natl Acad Sci U S A 89:4382-4386. CrossRef Medline

Taguchi K, Yoshinaka K, Yoshino K, Yonezawa K, Maekawa S (2005) Biochemical and morphologic evidence of the interaction of oligodendrocyte membrane rafts with actin filaments. J Neurosci Res 81:218-225. CrossRef Medline

Takahashi K, Yamanaka S (2006) Induction of pluripotent stem cells from mouse embryonic and adult fibroblast cultures by defined factors. Cell 126:663-676. CrossRef Medline

Tavori H, Fan D, Blakemore JL, Yancey PG, Ding L, Linton MF, Fazio S (2013) Serum proprotein convertase subtilisin/kexin type 9 and cell surface low-density lipoprotein receptor: evidence for a reciprocal regulation. Circulation 127:2403-2413. CrossRef Medline

Trapp BD, Andrews SB, Wong A, O'Connell M, Griffin JW (1989) Colocalization of the myelin-associated glycoprotein and the microfilament components, F-actin and spectrin, in Schwann cells of myelinated nerve fibres. J Neurocytol 18:47-60. CrossRef Medline

Tricaud N, Perrin-Tricaud C, Brusés JL, Rutishauser U (2005) Adherens junctions in myelinating Schwann cells stabilize Schmidt-Lanterman incisures via recruitment of p120 catenin to E-cadherin. J Neurosci 25: 3259-3269. CrossRef Medline

Waggener CT, Dupree JL, Elgersma Y, Fuss B (2013) CaMKII $\beta$ regulates oligodendrocyte maturation and CNS myelination. J Neurosci 33:1045310458. CrossRef Medline

Werner HB, Kramer-Albers EM, Strenzke N, Saher G, Tenzer S, OhnoIwashita Y, De Monasterio-Schrader P, Mobius W, Moser T, Griffiths IR, Nave KA (2013) A critical role for the cholesterol-associated proteolipids PLP and M6B in myelination of the central nervous system. Glia 61:567-586. CrossRef Medline

Yin X, Kidd GJ, Nave KA, Trapp BD (2008) P0 protein is required for and can induce formation of Schmidt-Lantermann incisures in myelin internodes. J Neurosci 28:7068-7073. CrossRef Medline

Zoltewicz SJ, Lee S, Chittoor VG, Freeland SM, Rangaraju S, Zacharias DA, Notterpek L (2012) The palmitoylation state of PMP22 modulates epithelial cell morphology and migration. ASN Neuro 4:409-421. CrossRef Medline 